\title{
Macaronesia as a Fruitful Arena for Ecology, Evolution, and Conservation Biology
}

\author{
Margarita Florencio ${ }^{1,2,3,4,5 *}$, Jairo Patiño ${ }^{3,6,7}$, Sandra Noguée, Anna Traveset ${ }^{9}$, \\ Paulo A. V. Borges ${ }^{3}$, Hanno Schaefer ${ }^{10}$, Isabel R. Amorim ${ }^{3}$, Miquel Arnedo ${ }^{11}$, \\ Sérgio P. Ávila ${ }^{12,13}$, Pedro Cardoso ${ }^{3,14}$, Lea de Nascimento ${ }^{15,16}$, \\ José María Fernández-Palacios ${ }^{15}$, Sofia I. Gabriel17,18, Artur Gil ${ }^{3,19}$, Vitor Gonçalves ${ }^{12,13}$, \\ Ricardo Haroun ${ }^{20}$, Juan Carlos Illera ${ }^{21}$, Marta López-Darias ${ }^{7}$, Alejandro Martínez ${ }^{22}$, \\ Gustavo M. Martins ${ }^{12}$, Ana I. Neto ${ }^{3,13 t}$, Manuel Nogales ${ }^{7}$, Pedro Oromí23, \\ Juan Carlos Rando ${ }^{23}$, Pedro M. Raposeiro ${ }^{12,13}$, François Rigal/,24, Maria M. Romeiras ${ }^{3,25}$, \\ Luís Silva ${ }^{12,13}$, Alfredo Valido ${ }^{7}$, Alain Vanderpoorten ${ }^{3}$, Raquel Vasconcelos ${ }^{26,27}$ and \\ Ana M. C. Santos $3,4,28,29$
}

Domingos Cardoso,

Federal University of Bahia, Brazil

Reviewed by:

Nuria Macías Hernandez, University of La Laguna, Spain

Qin Li,

Field Museum of Natural History,

United States

*Correspondence:

Margarita Florencio

margarita.florencio@uam.es;

mflorenciodiaz@gmail.com

${ }^{\dagger}$ Deceased

Specialty section:

This article was submitted to Biogeography and Macroecology,

a section of the journal

Frontiers in Ecology and Evolution

Received: 31 May 2021

Accepted: 04 October 2021

Published: 05 November 2021

Citation:

Florencio M, Patiño J, Nogué S,

Traveset A, Borges PAV, Schaefer H,

Amorim IR, Arnedo M, Ávila SP,

Cardoso P, de Nascimento L,

Fernández-Palacios JM, Gabriel SI,

Gil A, Gonçalves V, Haroun $R$

Illera JC, López-Darias M, Martínez A,

Martins GM, Neto Al, Nogales M,

Oromí P, Rando JC, Raposeiro PM,

Rigal F, Romeiras MM, Silva L,

Valido $A$, Vanderpoorten $A$

Vasconcelos $R$ and Santos AMC

(2021) Macaronesia as a Fruitful

Arena for Ecology, Evolution,

and Conservation Biology.

Front. Ecol. Evol. 9:718169.

doi: 10.3389/fevo.2021.718169
${ }^{1}$ Department of Life Sciences, Universidad de Alcalá, Alcala de Henares, Spain, ${ }^{2}$ Departamento de Ecologia, Universidade Federal de Goiás, Câmpus Samambaia, Goiânia, Brazil, ${ }^{3}$ Azorean Biodiversity Group, cE3c - Centre for Ecology, Evolution and Environmental Changes, Universidade dos Açores, Azores, Portugal, ${ }^{4}$ Centro de Investigación en Biodiversidad y Cambio Global (CIBC-UAM), Universidad Autónoma de Madrid, Madrid, Spain, ${ }^{5}$ Inland-Water Ecosystems Team -I-WET, Departamento de Ecología, Edificio de Biología, Facultad de Ciencias, Universidad Autónoma de Madrid, Madrid, Spain, ${ }^{6}$ Departamento de Botánica, Ecología y Fisiología Vegetal, Universidad de La Laguna, La Laguna, Tenerife, Spain, ${ }^{7}$ Island Ecology and Evolution Research Group, Instituto de Productos Naturales y Agrobiología (IPNA-CSIC), La Laguna, Tenerife, Spain, ${ }^{8}$ School of Geography and Environmental Science, University of Southampton, Southampton, United Kingdom, ${ }^{9} \mathrm{Global}$ Change Research Group, Institut Mediterrani d'Estudis Avançats (CSIC-UIB), Esporles, Mallorca, Spain, ${ }^{10}$ Plant Biodiversity Research, Department of Ecology and Ecosystem Management, Technical University of Munich, Freising, Germany, ${ }^{11}$ Department of Evolutionary Biology, Ecology and Environmental Sciences, Biodiversity Research Institute IRBio, Universitat de Barcelona, Barcelona, Spain, ${ }^{12}$ InBIO Laboratório Associado, Pólo dos Açores, CIBIO, Centro de Investigação em Biodiversidade e Recursos Genéticos, Ponta Delgada, Açores, Portugal, ${ }^{13}$ Departamento de Biologia, Faculdade de Ciências e Tecnologia, Universidade dos Açores, Ponta Delgada, Açores, Portugal, ${ }^{14}$ Laboratory for Integrative Biodiversity Research - LIBRe, Finnish Museum of Natural History, University of Helsinki, Helsinki, Finland, ${ }^{15}$ Island Ecology and Biogeography Group, Instituto Universitario de Enfermedades Tropicales y Salud Pública de Canarias (IUETSPC), Universidad de La Laguna (ULL), La Laguna, Tenerife, Spain, ${ }^{16}$ Long-Term Ecology Laboratory, Manaaki Whenua - Landcare Research, Lincoln, New Zealand, ${ }^{17}$ Departamento de Biologia Animal, Faculdade de Ciências, CESAM Centro de Estudos do Ambiente e do Mar, Universidade de Lisboa, Lisbon, Portugal, ${ }^{18}$ Departamento de Biologia, Universidade de Aveiro, Aveiro, Portugal, ${ }^{19}$ NAR - Research Institute for Volcanology and Risks Assessment, University of the Azores, Ponta Delgada, Azores, Portugal, ${ }^{20}$ Biodiversity and Conservation, Research Institute ECOAQUA, University of Las Palmas de Gran Canaria, Telde, Gran Canaria, Spain, ${ }^{21}$ Biodiversity Research Institute (CSIC-Oviedo University-Principality of Asturias), Oviedo University, Mieres, Spain, ${ }^{22}$ Molecular Ecology Group - MEG, Water Research Institute (IRSA), National Research Council of Italy (CNR), Verbania Pallanza, Italy, ${ }^{23}$ Departamento de Biología Animal, Edafología y Geología, Universidad de La Laguna, La Laguna, Tenerife, Spain, ${ }^{24}$ CNRS - Universiteé de Pau et des Pays de l'Adour - E2S UPPA, Institut des Sciences Analytiques et de Physico-Chimie pour l'Environnementet les Materiaux, Pau, France, ${ }^{25}$ Linking Landscape, Environment, Agriculture and Food - LEAF, Instituto Superior de Agronomia (ISA), Universidade de Lisboa, Lisbon, Portugal, ${ }^{26}$ BIOPOLIS Program in Genomics, Biodiversity and Land Planning, CIBIO, Centro de Investigação em Biodiversidade e Recursos Genéticos, InBIO Laboratório Associado, Universidade do Porto, Vairão, Portugal, ${ }^{27}$ Institute of Evolutionary Biology, CSIC-Universitat Pompeu Fabra, Barcelona, Spain, ${ }^{28}$ Global Change Ecology and Evolution Group - GLOCEE, Department of Life Sciences, Universidad de Alcalá, Alcalá de Henares, Spain, ${ }^{29}$ Terrestrial Ecology Group (TEG-UAM), Departamento de Ecología, Universidad Autónoma de Madrid, Madrid, Spain

Research in Macaronesia has led to substantial advances in ecology, evolution and conservation biology. We review the scientific developments achieved in this region, and outline promising research avenues enhancing conservation. Some of these discoveries indicate that the Macaronesian flora and fauna are composed of rather young lineages, not Tertiary relicts, predominantly of European origin. Macaronesia also seems to be an 
important source region for back-colonisation of continental fringe regions on both sides of the Atlantic. This group of archipelagos (Azores, Madeira, Selvagens, Canary Islands, and Cabo Verde) has been crucial to learn about the particularities of macroecological patterns and interaction networks on islands, providing evidence for the development of the General Dynamic Model of oceanic island biogeography and subsequent updates. However, in addition to exceptionally high richness of endemic species, Macaronesia is also home to a growing number of threatened species, along with invasive alien plants and animals. Several innovative conservation and management actions are in place to protect its biodiversity from these and other drivers of global change. The Macaronesian Islands are a well-suited field of study for island ecology and evolution research, mostly due to its special geological layout with 40 islands grouped within five archipelagos differing in geological age, climate and isolation. A large amount of data is now available for several groups of organisms on and around many of these islands. However, continued efforts should be made toward compiling new information on their biodiversity, to pursue various fruitful research avenues and develop appropriate conservation management tools.

Keywords: alien species, biodiversity hotspot, biotic interactions, extinction, long distance dispersal, reverse colonisation, speciation, volcanic oceanic islands

\section{INTRODUCTION}

Oceanic islands have long fascinated biologists, as they provide insights that have been incorporated into a number of ecological and evolutionary theories. Today, research on island systems is in the spotlight, with exciting new developments (e.g., Santos et al., 2016; Patiño et al., 2017; Whittaker et al., 2017; Valente et al., 2020). Many of these advances stem from studies performed partially or entirely in Macaronesia (sensu Engler, 1914), a region located in the Northeast Atlantic Ocean formed by the volcanic archipelagos of the Azores, Madeira, Selvagens, Canary Islands, and Cabo Verde (Figure 1).

Macaronesia comprises 40 islands and islets larger than $1 \mathrm{~km}^{2}$, covering a latitudinal range from $14.8^{\circ} \mathrm{N}$ to $39.7^{\circ} \mathrm{N}$ (Figure 1 and Table 1) and extending over a distance of almost $3,000 \mathrm{~km}$. This encompasses a strong climatic gradient from oceanic temperate climate in the Azores, to Mediterranean climate in Madeira, the Selvagens and Canary Islands, and warm arid climate in Cabo Verde (Fernández-Palacios, 2010). The geological age of the extant (emerged) islands and islets ranges from less than 35,000 years for Alegranza in the Canary Islands, to 25.7 million years (Ma) for Selvagem Grande. However, seamounts around Madeira and the Canary Islands are as old as $67 \mathrm{Ma}$ (Gettysburg near Madeira), which indicates that Macaronesia is at least twice or three times older than its oldest emerged land (FernándezPalacios et al., 2011; Ávila et al., 2016). Furthermore, these islands show contrasting levels of geographical isolation from the mainland, varying from $96 \mathrm{~km}$ off North Africa (Fuerteventura, Canary Islands) to more than $1,500 \mathrm{~km}$ (Flores, Azores) off the Iberian Peninsula (Fernández-Palacios, 2010; Figure 1). The boundaries of Macaronesia in the marine realm differ slightly, as Cabo Verde is described as pertaining to a different province, and the rest of the archipelagos are included in the Lusitanian province (Freitas et al., 2019).

The wide latitudinal, altitudinal, size, and climate variations of the Macaronesian islands are in part responsible for the diversity of habitats they host. These range from desert and semi-arid vegetation, typical for most of Cabo Verde and the driest areas of the Selvagens and Canary Islands, to the humid laurel and juniper forests characteristic of the Azores, Madeira, and the mid to high altitudes of the western and central Canary Islands (del Arco-Aguilar et al., 2010; FernándezPalacios, 2010). In addition, there are unique lentic and lotic ecosystems (Hughes and Malmqvist, 2005), as well as important microhabitats like subterranean cavities and volcanic hot springs (see Pipan et al., 2010). Macaronesia also straddles a wide range of marine habitats, which support a rich and yet incompletely known marine biota (Moro et al., 2003; Tuya and Haroun, 2009; Cordeiro et al., 2015).

In general, endemism appears to be high in many taxonomic groups, particularly from the terrestrial realm, like vascular plants, land snails and arthropods (Figure 2A and ESM1 in Supplementary Material). Indeed, a truly remarkable data is the percentage of endemic terrestrial mollusc species, that reaches over $41 \%$ in Azores (potentially close to $91 \%$ once the colonisation status is assigned to all species; Frias Martins, A., pers. comm.) and Cabo Verde, over $84 \%$ in Madeira (Teixeira, D., pers. comm.), and over $94 \%$ in the Canary Islands. Despite its small area, the Selvagens host over 50 endemic species (over the $15 \%$ of the total number of native species), sharing other endemisms with different Macaronesian archipelagos (Fernández-Palacios, 2010). In the Canary Islands, the level of endemism reaches 66\% in spiders (Cardoso et al., 2010), and $100 \%$ in reptiles (Loureiro et al., 2008; Arechavaleta et al., 2010; 


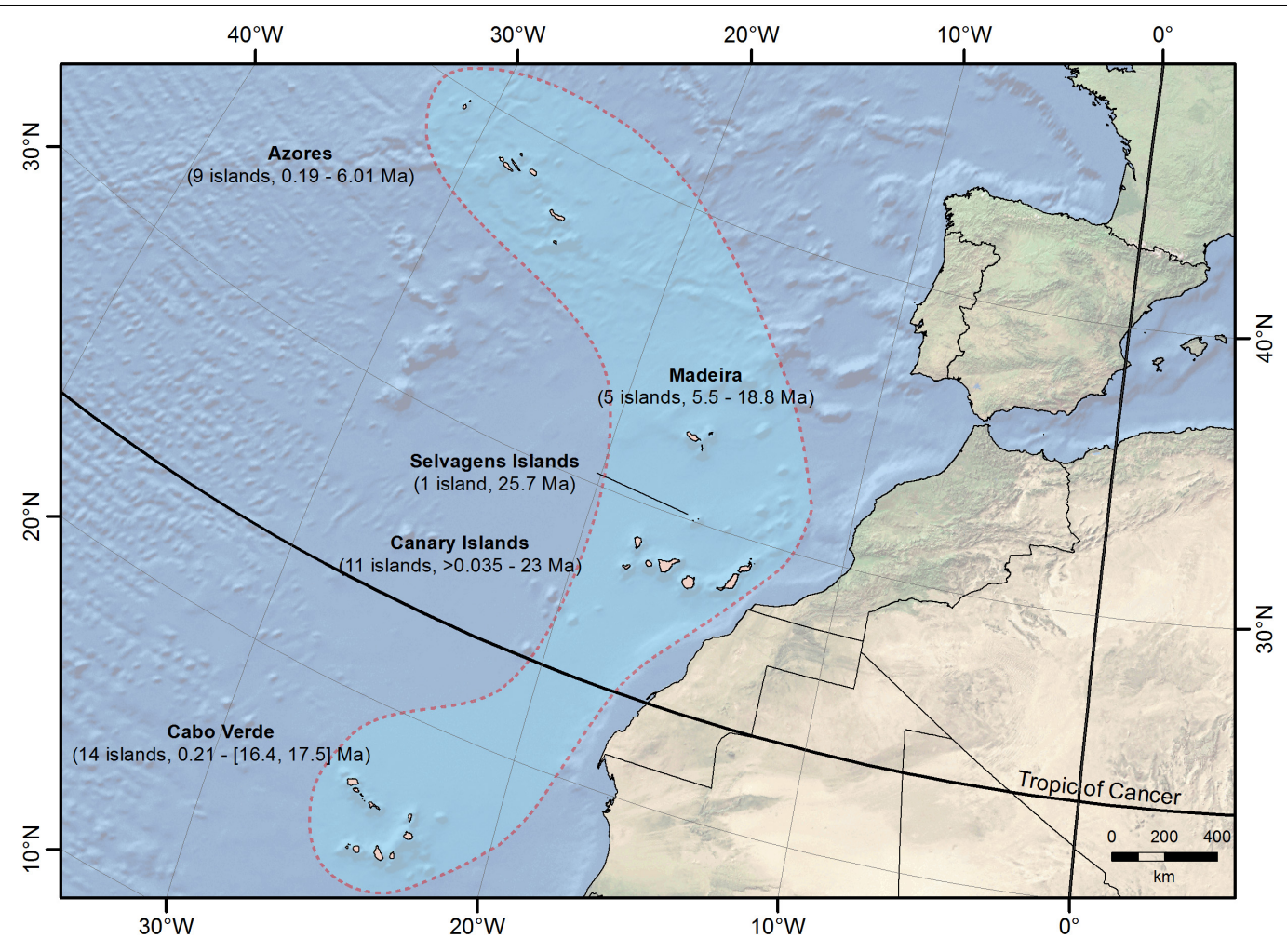

FIGURE 1 | Geographical location of the Macaronesian archipelagos, with indication of the number of islands and their geological age (only islets $>1 \mathrm{~km}^{2}$ were included; see Table 1).

Vasconcelos et al., 2013); within this context, almost $50 \%$ of the plant species of the Canary Islands are endemics (ReyesBetancort et al., 2008), with over $70 \%$ of them being considered single-island endemics (Carine and Schaefer, 2010). Finally, this pattern of high endemicity is not so evident in marine ecosystems (Figure 2B and ESM1 in Supplementary Material), where for many groups, the number of endemic species does not even reach 6\% of the archipelagic biodiversity (Freitas et al., 2019); the gastropods constitute the exception to this trend, particularly in Cabo Verde, where the number of endemic species represents over $44 \%$ of all native species (e.g., 86 Conus species inhabit this archipelago, being its majority endemic to Cabo Verde; Freitas et al., 2019).

Even though our knowledge of the flora and fauna of Macaronesia is still far from complete, the collective effort of systematists, ecologists, and biogeographers has resulted in the compilation of comprehensive data sets for species distributions (e.g., Arechavaleta et al., 2005; Borges et al., 2008, 2010; Arechavaleta et al., 2010; Romeiras et al., 2016a; Freitas et al., 2019), morphological traits (e.g., Schaefer et al., 2011; Whittaker et al., 2014; Henriques et al., 2017; Rigal et al., 2018; Macías-Hernández et al., 2020), ecological history and phylogenetic relationships (e.g., Emerson, 2002; Carine et al., 2010; Amorim et al., 2012; Caujapé-Castells et al., 2017), and species interactions (e.g., Dupont and Skov, 2004; Valido et al., 2004; Valido and Olesen, 2010; González-Castro et al., 2012). Nevertheless, despite the long-standing interest in Macaronesian biodiversity, our knowledge of the different archipelagos and taxa is still unbalanced, and the existing literature is rather heterogeneous (see Lobo and Borges, 2010; Romeiras et al., 2019). For example, the study of Cabo Verde's biota lags behind that of other Macaronesian archipelagos (Romeiras et al., 2020), which is probably associated with the fact that many endemic species only occur in habitats that are difficult to access, such as cliffs in the mountain areas (Neto et al., 2020). Certain taxonomic groups, like Platyhelminthes, Nematoda and Annelida, as well as the Bacillariophyta and Amoebozoa typical of freshwater habitats (but see Ritter et al., 2020; Gonçalves et al., 2021 for Madeira), are still poorly studied in most archipelagos (Figure $2 \mathrm{~A}$ and ESM1 in Supplementary Material). Even in the case of terrestrial arthropods, a group that has been intensively studied in the last decades, species description is far from complete, with estimates indicating that a large number of species remains unknown (Lobo and Borges, 2010).

Human activity has drastically transformed Macaronesia (e.g., Borges et al., 2019), leading to profound changes in habitat diversity and community composition over a relatively short period of time (del Arco-Aguilar et al., 2010; Triantis et al., 2010; Illera et al., 2012; Boieiro et al., 2018). Although the documented European colonisation of Macaronesia only started about 600 years ago, increasing evidence points to much earlier human arrivals in some of the archipelagos (see Förster et al., 2009; Gabriel et al., 2015; Rull et al., 2017). However, it was not until Europeans started to settle on the islands that intense land transformation and introduction of alien species led to a more sudden and profound alteration in most native terrestrial 
TABLE 1 | Main characteristics of the islands and islets larger than $1 \mathrm{~km}^{2}$ included in the Macaronesian archipelagos of the Azores, Madeira, Selvagens, Canary Islands, and Cabo Verde (compiled from Geldmacher et al., 2001; Torres et al., 2002; Madeira et al., 2005; Azevedo and Portugal Ferreira, 2006; Holm et al., 2006; Ancochea et al., 2010; Dyhr and Holm, 2010; Madeira et al., 2010; Ramalho, 2011; Ancochea et al., 2012; van den Bogaard, 2013; Aranda et al., 2014; Johnson et al., 2014; Ancochea et al., 2015; Costa et al., 2015; Ramalho et al., 2015; Ávila et al., 2016 and references therein; Ramalho et al., 2017; Samrock et al., 2018; Marques et al., 2020; Cornu et al., 2021).

\begin{tabular}{|c|c|c|c|c|c|c|c|}
\hline $\begin{array}{l}\text { Archipelago/ } \\
\text { Island }\end{array}$ & Latitude & Longitude & Area $\left(\mathrm{km}^{2}\right)$ & $\begin{array}{l}\text { Distance from } \\
\text { continent (km) }\end{array}$ & $\begin{array}{l}\text { Distance from } \\
\text { closest island } \\
(\mathbf{k m})\end{array}$ & $\begin{array}{c}\text { Geological age of the } \\
\text { oldest subaerial } \\
\text { lavas (Ma) }\end{array}$ & $\begin{array}{l}\text { Maximum altitude } \\
\text { (m asl) }\end{array}$ \\
\hline
\end{tabular}

\section{AZORES}

\section{Corvo}

Flores

Graciosa

Terceira

São Jorge

Faial

Pico

São Miguel

Santa Maria

MADEIRA

Porto Santo

Ilhéu da Cal

Madeira

Deserta Grande

Bugio

SELVAGENS

Selvagem Grande

CANARY ISLANDS

Alegranza

Montaña Clara

La Graciosa

Lanzarote

Lobos

La Palma

Fuerteventura

Tenerife

La Gomera

Gran Canaria

El Hierro

CABO VERDE

Santo Antão

São Vicente

Santa Luzia

Sal

Branco

Raso

São Nicolau

Boavista

Maio

Santiago

Ilhéu de Cima

Ilhéu Grande

Fogo

Brava

\section{$-31.1052$}

$-31.2025$

$-28.0113$

$-27.2123$

$-28.0292$

$-28.7013$

$-28.3336$

$-25.4819$

$-25.0998$

$-16.3422$

$-16.3855$

$-16.9991$

$-16.5205$

$-16.4856$

$-15.8656$

$-13.5148$

$-13.5365$

$-13.5032$

$-13.6418$

$-13.8245$

$-17.8583$

$-14.0365$

$-16.5563$

$-17.2326$

$-15.5932$

$-18.0066$

$-25.1701$

$-24.9678$

$-24.7452$

$-22.9314$

$-24.6682$

$-24.5861$

$-24.2562$

$-22.8139$

$-23.1606$

$-23.6248$

$-24.6330$

$-24.6768$

$-24.3843$

$-24.7055$
17

143

62

400

246

173

436

750

97

40

1.4

740

10

3

3

10

1

27.5

796

4

729

1,725

2,058

378

1,532

278

779

227

35

216

2.8

5.8

343

620

269

991

1.5

3

476

64

\section{1,858 \\ 1,864 \\ 1,596 \\ 1,520 \\ 1,584 \\ 1,657 \\ 1,610 \\ 1,368 \\ 1,376}

633

641

639

640

636

374

169

160

152

125

123

414

96

286

333

195

381

834

818

797

650

792

783

721

611

614

634

772

777

725

716

$\begin{array}{ccc}18 & 1.5 & 718 \\ 18 & 2.16 & 913 \\ 36 & 0.7 & 398 \\ 37 & 0.4 & 1,020 \\ 18 & 1.85 & 1,067 \\ 6 & 0.85 & 1,043 \\ 6 & 0.19 & 2,35 \\ 80 & 0.79 & 1,103 \\ 80 & 6.01 & 587\end{array}$

718

913

020

1,067

1,043

2,351

1,103

517

178

1,850

479

388

153

289

256

266

670

122

2,425

807

3,718

1,484

1,950

1,501

1,979

725

351

406

327

164

1,304

390

436

1,392

77

97

2,829

976

Islands are ordered according to their North-South latitude. Latitude and longitude refers the centroid of the islands. NA indicates unavailable information on the geological age; when there is no concrete date for the emergence of an island, data on geological age was represented as an interval of the most probable values. Ma and asl indicate Millions of years and Above sea level, respectively. 


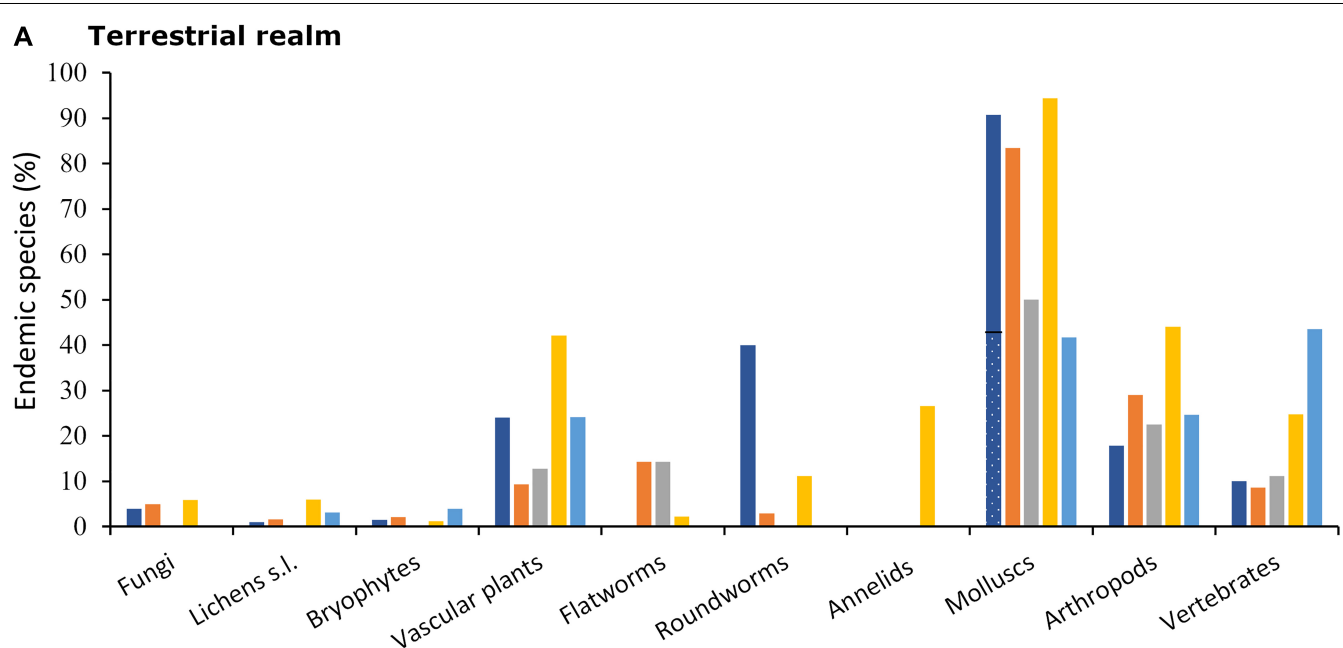

B Marine realm

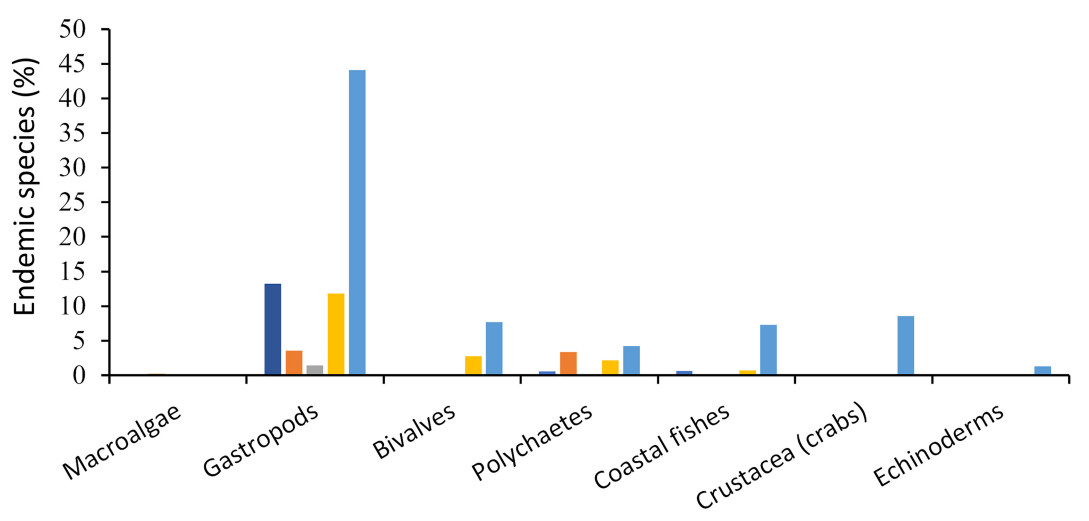

Azores

Madeira

Selvagens

Canary Islands

Cabo Verde

FIGURE 2 | Percentage of native species of several taxonomic groups that are endemic species of each Macaronesian archipelago (Azores, Madeira, Selvagens, Canary Islands, and Cabo Verde) at (A) the terrestrial and (B) the marine realms. Information on the terrestrial biota was extracted from Arechavaleta et al. (2005), Borges et al. (2008, 2010), Miralles et al. (2011), Vasconcelos et al. (2012b, 2020), and Biodiversity Data Bank of the Canary Islands (2021). Data on marine taxa was extracted from Freitas et al. (2019) and Neto et al. (2021a,b,c), and unpublished data from one of the authors (Ávila, S.P.) regarding bivalves. The proportion of the endemic species was calculated over the number of native species, which included those considered probably or possibly native. Only extant species and breeding birds were considered. Lichens s.I. includes lichenicolous fungi, Vascular plants include Spermatophyta, ferns, and fern allies, Arthropods include Tardigrada, and Crustacea only refers Brachyura (crabs). The dotted area in the bar of the Azorean Molluscs indicates the existence of some uncertainty regarding the proportion of endemic species (43-91\%; Frias Martins, A., pers. comm). In the case of Madeira, we have considered 25 additional species that have recently been classified as native based on fossil evidence; Teixeira, D., pers. comm.). Diatoms and amoebae are not represented because of their incomplete information. Also,

Platyhelminthes (flatworms) and Annelids show the same value in Madeira and Selvagens because the source literature does not discriminate between the two archipelagos. No data was reported for the Platyhelminthes, Nematoda (roundworms) and Annelida in Cabo Verde, and for Nematoda and crustaceans Brachyura (crabs) in Selvagens (see ESM1 in Supplementary Material for detailed information).

and aquatic ecosystems (Malmqvist et al., 1995; Triantis et al., 2010; Raposeiro et al., 2017; Lamelas-López et al., 2021). Marine ecosystems are also affected by similar anthropogenic pressures, mainly through overexploitation of biological resources (Martins et al., 2008, 2012) and increasing urbanisation of coastal areas (Cacabelos et al., 2016a,b; Martins et al., 2016). Climate change also represents a threat to Macaronesian diversity, as indicated by studies modelling the distribution of endemic and native bryophytes, vascular plants, and arthropods under different scenarios of climate change (Ferreira et al., 2016; Patiño et al., 2016).

The outstanding biodiversity of the Macaronesian archipelagos, together with the geographical, environmental and historical idiosyncrasies of their islands have fuelled a continuously increasing number of ecological, evolutionary, and conservation studies. Here, we review the most important findings of Macaronesian studies and identify further challenges in island biology that can be addressed in this insular system.

\section{HISTORY AND ORIGIN}

\section{Young Lineages Instead of Tertiary Relicts}

Macaronesia has primarily been defined as a biogeographical region based on its terrestrial flowering plant species. Engler (1879) suggested that the Macaronesian flora was mostly a 
relict of a formerly widespread subtropical flora covering southern Europe and North Africa during the Palaeogene and Neogene. Increasing evidence from dated phylogenies suggests that Macaronesian endemics are often much younger than the age of emergence of the islands they inhabit, casting doubts on Engler's hypothesis [e.g., vascular plants (Jones et al., 2014; Kondraskov et al., 2015), bryophytes (Patiño and Vanderpoorten, 2015), birds (Illera et al., 2012, 2016; Valente et al., 2017), spiders (Planas and Ribera, 2014), beetles (Emerson et al., 1999; Amorim et al., 2012), lichens (Sérusiaux et al., 2011), reptiles (Romeiras et al., 2019), and marine gastropods (Duda and Rolán, 2005; Baptista et al., 2019)]. Even the iconic Macaronesian laurel forest, long viewed as an assemblage of Tertiary relictual and palaeoendemic elements (see Fernández-Palacios et al., 2011) may be composed of mainly young and recent colonisers (Kondraskov et al., 2015). This pattern coincides with other archipelagos, for example New Caledonia, with a biota mainly formed by recent clades, despite being the oldest oceanic island in the world (Nattier et al., 2017). However, the complex geological dynamics of Macaronesia has led to the emergence and disappearance of several (palaeo-)islands (Fernández-Palacios et al., 2011), which could have served as stepping-stones and refugia for the persistence of older lineages, as in other archipelagos (Heads, 2010). Nevertheless, phylogenetic evidence for the persistence of "living fossils," whose origin predates their native islands, is extremely rare and limited to very few species (e.g., the moss Hedenasiastrum percurrens; Aigoin et al., 2009).

\section{Long- and Short-Distance Dispersal in Macaronesia}

The ancestors of most extant Macaronesian lineages had to overcome the long distances that separate the islands from the mainland. Accordingly, many Macaronesian plants (e.g., Patiño et al., 2013; García-Verdugo et al., 2019), lizards (Carranza et al., 2000) and marine molluscs (e.g., Ávila et al., 2012; Faria et al., 2017) show some adaptations to long distance dispersal (LDD). However, there is also evidence from the Azorean flora indicating that many plant species lack traits related to LDD (Heleno and Vargas, 2015), and that species ability to track its climatically suitable areas within an island is not strongly related with LDD syndromes (Leo et al., 2021). Notably, non-standard LDD mechanisms poorly evaluated in island systems have been described for Macaronesia. These include secondary seed dispersal mediated by predatory birds feeding on frugivorous birds and lizards, which carry seeds in their digestive system (Nogales et al., 2012; Padilla et al., 2012; Viana et al., 2016; but see Grant et al., 1975, regarding the Galápagos), and dispersal through mega-landslides (García-Olivares et al., 2017).

Colonisation and establishment of many plants is mediated by generalist seed dispersers. In the Canary Islands and Madeira, such a function is widely performed by frugivorous lizards (Sadek, 1981; Valido and Nogales, 1994; Nogales et al., 2016; Pinho et al., 2018), following a pattern common in many islands worldwide (Hervías-Parejo et al., 2019; Valido and Olesen, 2019). Lizard-plant interactions result in a relatively short-distance dispersal pattern of seed distribution, with the lizard Gallotia stehlini dispersing seeds over almost $100 \mathrm{~m}$ on Gran Canaria (Pérez-Méndez et al., 2016). In contrast, birds can disperse viable seeds over short and long distances within and between islands (Nogales et al., 2001; López-Darias and Nogales, 2016).

\section{Macaronesia as Refugium and Source of Biodiversity for the Adjacent Mainland}

Due to their buffered climate and larger sizes during glacial periods, oceanic islands were traditionally considered as sinks for continental terrestrial biotas (Wilson, 1961). However, a growing body of phylogenetic evidence suggests that islands also act as sources of continental diversity (Jønsson and Holt, 2015). Macaronesia has acted as both refugium (Vargas, 2007; Caujapé-Castells, 2011; Fernández-Palacios et al., 2011) and, at least to a certain extent, as a source of de novo species for neighboring continental regions (Patiño et al., 2015). Backcolonisation from islands to continental areas, from which the island ancestors originated ("boomerang events" sensu CaujapéCastells, 2011), was first postulated by Ball and Hooker in 1878 for Macaronesia (Fernández-Palacios and Whittaker, 2020), and more than a century later was confirmed for the genera Aeonium (Mort et al., 2002) and Convolvulus (Carine et al., 2004). Further evidence derives from bryophytes and spermatophytes (e.g., Fernández-Mazuecos and Vargas, 2011; Hutsemékers et al., 2011), and beetles (Machado et al., 2017). Similar processes have later been described in New Zealand and New Caledonia (Condamine et al., 2017). The close proximity of some of the Macaronesian islands (Canary Islands and Cabo Verde) to their continental species pools, the changes in island surface area, isolation and predominant wind and ocean currents through time, together with the emergence of seamounts during glacial periods (Fernández-Palacios et al., 2011; Rijsdijk et al., 2014) may have allowed even greater connectivity between these landmasses in the past.

\section{High or Reduced Genetic Diversity of Island Populations?}

The few individuals that successfully arrive and colonise islands carry just a subset of the genetic variation in the parental continental populations (Frankham, 1997; Clegg, 2010). In Macaronesia, isolation after colonisation seems to have driven both genetic and phenotypic divergence in Berthelot's pipit (Anthus berthelotii), and not geographical distance or environmental differences (Spurgin et al., 2014). In contrast, Stuessy et al. (2012) suggested that genetic signatures of founder effects rarely persist over evolutionary time-scales in island plants. Indeed, a growing body of empirical evidence for Macaronesian bryophytes and angiosperms suggests that genetic diversity is often substantially higher than in the continental source populations (Fernández-Mazuecos and Vargas, 2011; Laenen et al., 2011; Desamoré et al., 2012; García-Verdugo et al., 2015; Patiño et al., 2015). Strikingly, the invasive house mouse (Mus musculus domesticus) in Madeira also follows this pattern. Evidence supports an initial introduction event about one millennium ago (Förster et al., 2009; Rando et al., 2014), with subsequent in situ genetic diversification that resulted in 
six chromosomal races distributed around the island (BrittonDavidian et al., 2000). This rapid diversification can be explained by meiotic drive due to a biased segregation of chromosomes to oocytes during female meiosis. The underlying biological mechanism involves differential centromere strength (a trait with natural variation among populations), predicting the direction of drive (Chmatal et al., 2014). This can result in the rapid fixation of distinct chromosomal combinations and, consequently, an increase in genetic diversity.

\section{COMMUNITY ECOLOGY IN MACARONESIA}

After arrival on islands, ecological processes act as major drivers of island community assembly, along with speciation and extinction events (Figure 3). MacArthur and Wilson (1963, 1967) highlighted the dynamic nature of the processes leading to community composition changes through time. Since not all species are equally likely to colonise islands, one general assumption is that island biotas are impoverished and taxonomically "imbalanced"-a phenomenon known as disharmony-when compared to adjacent mainland regions. As a consequence of this "vacant ecological space," some species might have the opportunity to broaden, or even shift their niche width through "ecological release" (Diamond, 1970). Prominent examples are the Azorean endemic bat Nyctalus azoreum, which exhibits the rare behaviour of being active during the day, probably due to the absence of avian competitors or predators (Moore, 1975; see Chua and Aziz, 2018, for a similar case in Malaysia). The Cabo Verde giant gecko Tarentola gigas, which preys on birds (Pinho et al., 2018) in the absence of mammalian top predators, is another example. Ecological release also occurs in different Macaronesian insect groups, in both terrestrial (Ribeiro et al., 2005; Stüben et al., 2010; Santos et al., 2011) and aquatic ecosystems (Raposeiro et al., 2012).

\section{Mutualistic Interactions}

Species interactions associated with pollination and seeddispersal processes can influence large-scale biodiversity patterns. In insular systems, pollination networks commonly show distinctive and idiosyncratic ecological characteristics known as insular pollination syndromes (Valido and Olesen, 2010). For example, in the Canary Islands, generalist lizards and birds are important pollinators and seed dispersers (Valido et al., 2004; Valido and Olesen, 2010, 2019; Hernández-Teixidor et al., 2019), an uncommon behaviour in mainland systems (Olesen and Valido, 2003). Notably, Macaronesian pollinators tend to visit a wider range of plant species than their mainland relatives ("interaction release" sensu Traveset et al., 2015).

These particularities of island mutualistic networks suggest they may be notably vulnerable to similarly particular disturbances (see Heleno et al., 2013; Traveset et al., 2013 for Galápagos). González-Castro et al. (2012) compared the seed dispersal network structure of thermophilous woodland on Tenerife (Canary Islands) to mainland woodland and found that the lower number of species and greater specialisation on the island led to the prevalence of more symmetrical interactions, compared to the mainland. Also, Nogales et al. (2016) demonstrated that Canarian seed dispersal networks are highly nested (stable against disassembly) but weakly modular (the ensemble of species that interact more intensively), and therefore highly vulnerable to extinction cascades.

\section{Alien Species}

The introduction of alien species is one of the main threats to biodiversity in Macaronesia and worldwide. More than $70 \%$ of vascular plants and more than $50 \%$ of arthropod species in the Azores are aliens (Silva et al., 2008). Especially successful invaders in Macaronesia include the plants Cenchrus spp., Hedychium gardnerianum, Pittosporum undulatum and Ulex europaeus, as well as vertebrates like cats (Felis sylvestris), goats (Capra hircus), Corsican mouflons (Ovis aries musimon), Barbary sheep (Ammotragus lervia), rats (Rattus rattus and $R$. norvegicus), house mice (Mus musculus domesticus), rabbits (Oryctolagus cuniculus), and Californian kingsnakes (Lampropeltis californiae). The spread of alien fish in the absence of native predators is an important threat to freshwater systems in Macaronesia (Ribeiro et al., 2009), impacting trophic cascades and ecosystem functioning (Skov et al., 2010; Buchaca et al., 2011; Raposeiro et al., 2017). A high number of alien species have been also reported in the marine realm of Macaronesia, with shipping as the most likely vector of these introductions (Chainho et al., 2015).

Schaefer et al. (2011) found that for the Azorean flora, alien species that are phylogenetically distant from native species are more likely to become invasive, corroborating Darwin's naturalisation hypothesis. Moreover, Padrón et al. (2009) and Picanço et al. (2017) showed that endemic and native supergeneralist pollinators included new plant invaders in their set of food plants and thereby may help the establishment of alien and invasive plants. Indeed, alien bees pollinate most of the endemic Azorean flora (Weissmann et al., 2017). However, domestic honeybees (Apis mellifera) disrupt the structure and functionality of the plant-pollinator networks in Teide National Park (Tenerife, Canary Islands), reducing diversity and interaction links among wild pollinators, their hierarchical organisation, and the reproductive success of some endemic plants (Valido et al., 2002, 2019; Dupont et al., 2004). Also, alien arthropods added novel trait space in the Azores (Whittaker et al., 2014), and might play important roles in providing and maintaining some key ecosystem functions, particularly in anthropogenic systems such as cattle pastures (Rigal et al., 2018).

\section{SPECIATION, DIVERSIFICATION, AND EXTINCTION IN MACARONESIA}

Ecological opportunities on islands may foster diversification and speciation processes. New ecological opportunities are created when new habitats become available, such as subterranean environments that emerge as a consequence of present and/or past volcanic activity. For example, many phylogenetic and phylogeographical studies on endemic radiations of the Macaronesian arthropods include troglobiont species, such as 


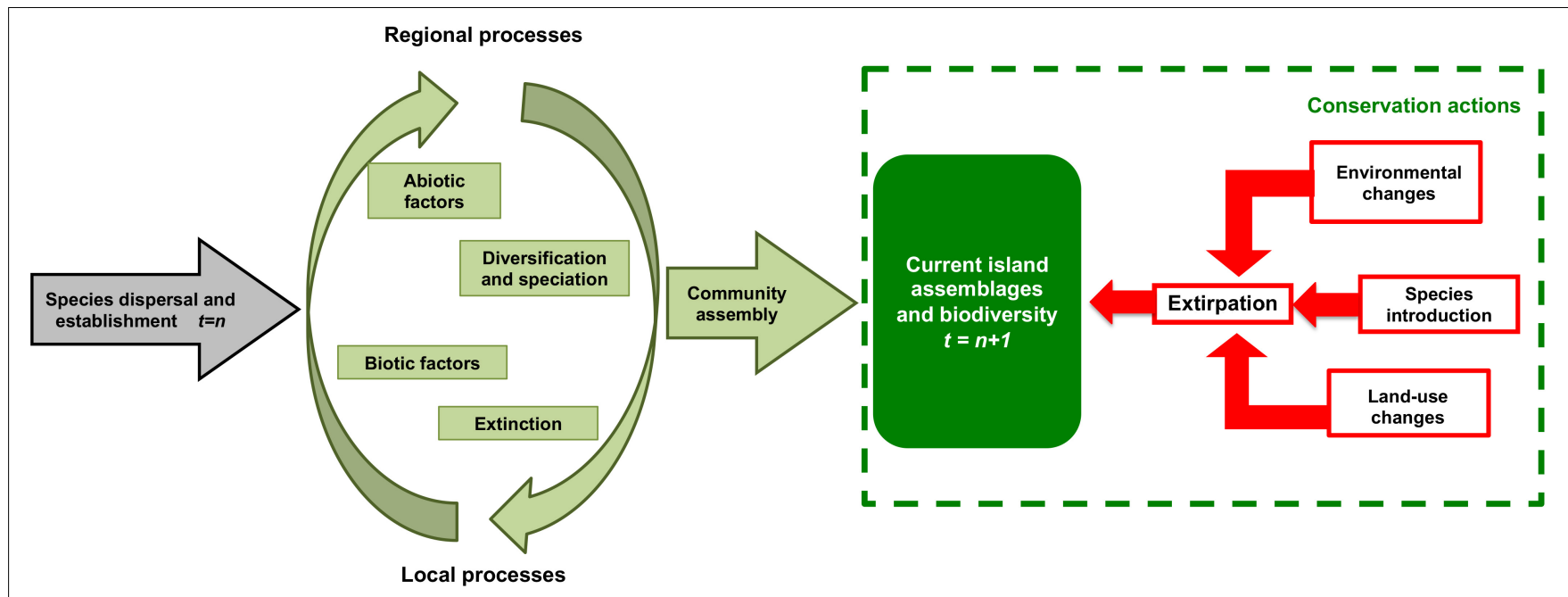

FIGURE 3 | Processes leading to community assembly in island biotas. The grey arrow represents dispersal from the species pool since historical times ( $t=n)$. Species able to colonise an island are subject to several processes and factors acting at the regional and local scales (some examples of these are indicated inside the two green arrows conforming a circle), which can lead to community assembly (large green arrow) and to the current biodiversity on islands (green box;

$t=n+1)$. The extant island biodiversity is a result of speciation and diversification under regional and local abiotic constraints and biotic interactions. Current island assemblages and biodiversity are affected by anthropogenic disturbances such as environmental changes, species introductions and land-use changes (red arrows) that can lead to extirpation of species (red box), and are thus often targeted by conservation actions (green dashed box).

Dysdera spiders (Arnedo et al., 2007), Palmorchestia sandhoppers (Villacorta et al., 2008), Trechus ground beetles (Amorim, 2005; Contreras-Díaz et al., 2007), and Laparocerus weevils (Machado et al., 2017). Examples of radiations known to be adaptive are found among flowering plants (e.g., Echium-García-Maroto et al., 2009; Aeonium-Jorgensen and Olesen, 2001; Mort et al., 2001) and reptiles (e.g., Gallotia-Cox et al., 2010; TarentolaCarranza et al., 2000; Vasconcelos et al., 2010). These taxa correspond to examples of diversification events associated with niche lability, in which closely related species present contrasting niches. Such niche differentiation can be reflected in current species distribution, as occurs in some plant clades in the Canary Islands, where closely related taxa present different climatic niches, particularly in allopatry (Steinbauer et al., 2016). However, not all diversification processes have arisen from changes in species niches; niche conservatism, which can be described as the tendency for ancestral niche and ecological characteristics to remain unchanged through time and space (Wiens and Graham, 2005), has also been an important speciation outcome in different taxa (e.g., Helianthemum-Albaladejo et al., 2021). Notably, the flora of the Azores is characterised by a limited incidence of adaptive radiations, contrasting with other Macaronesian archipelagos (Carine and Schaefer, 2010); the debate about the drivers of this pattern has pinpointed past climatic conditions, age, area and environmental homogeneity as the most plausible causes (Carine and Schaefer, 2010; Carine et al., 2012; Triantis et al., 2012).

Species interactions could also have fuelled species diversification in Macaronesia. By combining morphological data, radiocarbon dating, and molecular data, Rando et al. (2010) recovered an ecological interaction (resource competition) between sympatric extinct and extant finches of Tenerife for approximately $1 \mathrm{Ma}$. This interaction led to variations in bill size, as more famously known from the Galápagos finches (Grant and Grant, 2006). The presence on other Macaronesian islands of other extinct granivorous birds with significant variation in bill size suggests that character displacement between extinct and extant birds frequently occurred, to minimise competition for food (Rando et al., 2010).

The interaction between dispersal limitations and geological dynamics as drivers of diversification has attracted increased attention (Anderson et al., 2009; Fernández-Palacios et al., 2011; Rijsdijk et al., 2014; Ávila et al., 2015a). A history of massive landslides and their associated mega-tsunamis in Macaronesia allowed this question to be addressed at the within-island level (cf. Paris et al., 2018). Studies on endemic lizards and beetles point to an important role of these geological events in shaping the genetic structure of endemic lineages (Brown et al., 2006; García-Olivares et al., 2017) and, in combination with past climate oscillations, the community-wide diversification patterns across beetle species over a limited spatial scale (Salces-Castellano et al., 2020). Lava flows, that appear during volcanic activity, have led to population extirpation and the appearance of dispersal barriers, greatly affecting phylogeographic patterns and speciation (e.g., Gallotia-Bloor et al., 2008). The dynamics of sea-level changes, particularly those that occurred in the Quaternary, have affected island area, isolation and connectivity, which consequently influenced migration, extinction, and speciation, leaving an important imprint in current island richness, particularly of endemic species (Fernández-Palacios et al., 2011; Rijsdijk et al., 2014; Weigelt et al., 2016). As a consequence, Lanzarote and Fuerteventura, two islands that were connected in the Last Glacial Maximum $(\sim 18,000$ years ago), share more insect and 
plant species than any other islands within the Canary Islands (Fernández-Palacios et al., 2011; Rijsdijk et al., 2014), and in Cabo Verde, only Tarentola spp. that occurred on islands connected during this period share haplotypes (Vasconcelos et al., 2010). Such dynamics also affected marine diversity, for example through its effects on sea-surface currents and dispersal routes (e.g., Ávila et al., 2009; Sousa et al., 2021), and on the characteristics of the intertidal zone (Ávila, 2013). Recent palaeocological studies have related marine ecological traits (e.g., the substrate where animals live) with extirpation/extinction trends, putting in evidence the impact of sea-level changes on insular shallow-water benthic marine communities (Ávila et al., 2009). Also, species range contractions and extensions (e.g., Persististrombus spp. and Conus spp., respectively; Meco et al., 2002; Ávila et al., 2015a, 2016) have been documented, and show the impact of climatic global changes associated with Pliocene climatic deterioration and the abrupt Pleistocene glacial/interglacial transitions (the so-called "Terminations") on species distributions.

\section{Extinction in Macaronesia}

Natural extinctions have been driven by ancient changes in climate and habitat. Oxygen isotope data suggest that most of the Pliocene marine fauna of the Azores became extinct 3.6-3.3 Ma ago as a result of glaciation (Ávila et al., 2015b, 2016; Santos et al., 2015). In addition, volcanism and geological catastrophes such as massive landslide events and mega-tsunamis, can also act as important drivers of island-wide natural extinction events (Anderson et al., 2009). However, human arrival has greatly impacted island biotas, accelerating species extinctions on islands (e.g., Triantis et al., 2010; Russell and Kueffer, 2019) to the point of influencing our understanding of basic evolutionary patterns (e.g., body size evolution toward dwarfism or gigantism on island species; Faurby and Svenning, 2016).

Canarian giant lizards (Gallotia spp., Lacertidae) underwent a strong defaunation process after human colonisation, with negative consequences on the seed dispersal distances and genetic variation of endemic plants, such as Cneorum (Neochamaelea) pulverulentum (Pérez-Méndez et al., 2018). Palaeobiological evidence also points to the extinction of several other species after human arrival, such as most flightless or weak-flying ground-nesting Canarian birds, as suggested by radiocarbon dating of bone collagen (Illera et al., 2016). In total, more than 20 endemic and many non-endemic vertebrate species that lived during the Upper Pleistocene-Holocene became extinct in Macaronesia, such as the iconic Cocteau's giant skink of Cabo Verde or the Macaronesian rails species (Vasconcelos et al., 2013; Alcover et al., 2015; Rando et al., 2020). Long-term fossil pollen and charcoal records have shown a decline in native plant diversity (possibly including some tree genera now absent as natives on Tenerife such as Quercus and Carpinus), introduction of non-native forest species (e.g., Cryptomeria japonica and Pinus pinaster in the Azores), and an increasing rate of fire occurrence after human arrival (de Nascimento et al., 2009, 2016; Gabriel et al., 2015; Rull et al., 2017). In the marine realm, the overexploitation of biological resources, such as the case of limpets, crustaceans and fishes, may also cause the extirpation of keystone species in coastal trophic chains (Navarro et al., 2005; Martins et al., 2008, 2010).

\section{BIODIVERSITY PATTERNS AND MODELS}

\section{Species Distributions}

Species abundance distributions (SADs), which are key descriptors of community structure, have been little investigated in island empirical studies (but see Ulrich and Zalewski, 2006, for lake islands, and Garcillán and Ezcurra, 2011, regarding Guadalupe Island, Baja California). In Macaronesia, Azorean arthropod communities are dominated by a few highly abundant single-island endemic species that may be assumed to be well adapted to specific island environmental conditions (Fattorini et al., 2016). These SADs of the Azorean arthropods follow a power law pattern when plotted according to sample size, which is similar to that observed for tropical tree SADs; this might indicate a general pattern in ecology (Borda-de-Água et al., 2017). Considered as one of the most general patterns in nature, the island species-area relationship (ISAR) has been widely studied using data from many archipelagos, namely those pertaining to Macaronesia (e.g., Cardoso et al., 2010; Santos et al., 2010; Aranda et al., 2013). Although the ISAR has mostly been studied in terrestrial systems, interest in evaluating it in marine and other aquatic systems is growing (Dawson, 2016). As an example in the marine realm, Tuya and Haroun (2009) found that intra-archipelago differences in species richness of Macaronesian macroalgae are largely related to variations in island perimeter (a proxy for island area).

\section{The General Dynamic Model of Oceanic Island Biogeography}

Islands are dynamic entities that have undergone climatic and geological changes through time. The General Dynamic Model of oceanic island biogeography (GDM; Whittaker et al., 2008; Borregaard et al., 2017) considers the effect of geological dynamics of oceanic islands on their diversity. The GDM has been intensively tested in Macaronesia, namely with arthropods (Borges and Hortal, 2009; Cardoso et al., 2010), reptiles (Vasconcelos et al., 2010), snails (Cameron et al., 2013), and bryophytes (Patiño et al., 2013; Aranda et al., 2014), and also in the sea (Ávila et al., 2018). While these evaluations show the potential of the GDM for predicting patterns of island species richness through time, they also pinpoint the need to account for island and taxon particularities when applying biogeographical models (see Borges and Hortal, 2009). The third component of the original theory of island biogeography, geographical isolation, was only recently included within the GDM framework, with Macaronesia (and Hawaii) being used as testing grounds (Patiño et al., 2013; Carvalho et al., 2015).

Recent studies on Macaronesian islands showed that the hump-shaped relationship between species richness and island geological age also holds for network interactions and genetic diversity, in which island age and dynamics act as regional drivers of plant-pollinator network complexity (see Trøjelsgaard et al., 2013 for an example in the Canary 
Islands). Similarly, Vasconcelos et al. (2010) showed that volcanism and habitat diversity appear to be the main factors explaining the genetic diversity of Tarentola geckos in Cabo Verde, since they are both tightly linked with island ontogeny as postulated by the GDM. The importance of island age for explaining diversity patterns is also present in the marine realm. On a broader Atlantic archipelagos' context, Hachich et al. (2015) found a linear relationship between reef fish diversity and island age. More recently, Fernández-Palacios et al. (2016) developed a Glacial Sensitive Model (GSM) of oceanic island biogeography partially based on Macaronesian islands, which includes the role of glacial and interglacial periods in the GDM. Building on these models, Ávila et al. (2019) developed the Sea-Level Sensitive dynamic model (SLS) of marine island biogeography. This model offers predictions on how immigration, colonisation and in situ speciation rates affect marine biodiversity around oceanic islands.

\section{NATURE CONSERVATION IN MACARONESIA}

Several political, scientific and social initiatives toward improving conservation practices and public awareness have been established in Macaronesia. For example, the costeffectiveness of conservation and governance policies can be improved by relying on island ecosystem-based management (Calado et al., 2016; Gil et al., 2016a), stakeholder engagement and public participation (Gil et al., 2011, 2016b), and funding to support and strengthen ecosystem functions and services delivery (e.g., Cruz et al., 2011; Fernandes et al., 2015). Hence, the last decade has witnessed the publication of important studies aiming to assist local and regional decision-making systems in moving toward more effective nature conservation planning and management policies in Macaronesia. Special attention has been given to "Natural Protected Areas" design and effectiveness (Vergílio et al., 2016; Gil et al., 2017). Several indices for the selection of priority areas for conservation have been developed based on Macaronesia (Gaspar et al., 2011; Borges et al., 2012; Cardoso et al., 2013). An innovative, cost-effective and replicable methodology has also been developed for protecting genetic diversity in reserves (Vasconcelos et al., 2012a). Furthermore, knowledge gathered in Macaronesia has been also used to propose several methodologies and standardised protocols for conservation assessment of endemic species (Borges et al., 2018). Identifying top-priority species is particularly useful for designing conservation strategies. However, applying IUCN criteria (IUCN Standards and Petitions Subcommittee, 2017) to oceanic islands may have serious shortcomings (Martín, 2009; Cardoso et al., 2011; González-Mancebo et al., 2012), leading, for example, to assigning species to higher threat categories (Romeiras et al., 2016a). Therefore, species risk tolerance should be adjusted within island systems (Romeiras et al., 2016b).

Macaronesia also served as the basis for developing successful innovative approaches for alien species management on islands, including prevention, early detection, eradication and control of invaders, as well as proper legislation. For instance, a list of the priority TOP 100 invasive alien species in Macaronesia has been compiled (Silva et al., 2008), based on their known impacts upon native and endemic biodiversity and the feasibility of successful control. Furthermore, the Canary Islands, Madeira and Selvagens have provided examples of successful eradication and control schemes for rabbits, cats, mice, and plants (e.g., Bell, 2001; Olivera et al., 2010). In the Azores, a regional programme to control invasive alien plants in sensitive areas has revealed the importance of maintenance to prevent alien regrowth (Costa et al., 2013).

Several initiatives and programmes have led to the successful restoration of different endemic and native species. One emblematic threatened species in Macaronesia is the Azorean endemic bullfinch (Pyrrhula murina), a species that has recovered through habitat restoration and removal of alien species ("LIFE Priolo" project; SPEA, 2006); such actions have led to positive impacts not only on the target species, but also on native plants, insects and birds (Heleno et al., 2010). The giant lizard Gallotia simonyi and the Raso lark Alauda razae are other threatened endemic species that have been the target of strong conservation actions, like breeding programmes and reintroductions in small islets and islands of the Canary Islands and Cabo Verde, respectively (Salvador, 2015; Brooke et al., 2020); recent innovative actions that will enhance future reintroductions of the giant lizards, include training procedures where individuals raised in captivity learn to avoid predators (Burunat-Pérez et al., 2018).

\section{MACARONESIA AND FUTURE PROSPECTS IN ISLAND BIOLOGY}

We have highlighted a large number of research questions addressed using Macaronesia as a natural laboratory. The comprehensive ecological and evolutionary datasets gathered so far in different studies have already proven essential for current understanding of island biology. Unfortunately, many extant and extinct species still remain undescribed and some environments underexplored (e.g., subterranean, marine), and thus our knowledge is far from complete in Macaronesia (Lobo and Borges, 2010). More efforts should be made toward gathering basic information on species taxonomy, distribution, abundance, evolution and ecology. Still, there are many research avenues to be explored (e.g., Santos et al., 2016; Patiño et al., 2017), and below we point out the importance of these archipelagos for pursuing them.

The proximity of some Macaronesian islands to the adjacent mainland provides a well-suited geological set-up for islandmainland comparisons, for instance to evaluate genetic diversity, gene-flow patterns and the importance of islands in generating mainland diversity. The genetic imprints of founder events and the impact of historical geological and climatic events (or their absence) can be tested with the increasing number of locally relevant population genetics and genomic datasets available, and applying approaches based on multitaxon comparisons that could help understand how much biotic interchange has occurred not only between islands and the mainland, but also 
between archipelagos (see e.g., Antonelli et al., 2018). Although ecological opportunities are considered as potential drivers of the remarkable radiations that occurred in the region, the degree to which isolation affects such speciation processes is still not entirely understood (Patiño et al., 2017). The combination of phylogenetic information and trait data that are increasingly becoming available in this region will allow understanding the processes behind niche evolution, particularly how labile and conserved ecological attributes, together with the availability of novel habitats, affect speciation and lineage diversification (see Edwards and Donoghue, 2013). The unique subterranean ecosystems and fossiliferous outcrops of Macaronesia are windows into past insular terrestrial and marine biotas, providing opportunities to evaluate the role of vacant ecological space, trait lability and isolation on diversification and speciation. Island-mainland comparisons can also be extended to different ecological questions, namely those related with the processes leading to community assembly and rarity (e.g., Santos et al., 2011; Borda-de-Água et al., 2017; Boieiro et al., 2018). Future research could therefore focus on comparing species-abundance distribution patterns between the two settings in order to understand the generality of such relationship (e.g., following, Borda-de-Água et al., 2017), or contrasting islands and mainland trait and phylogenetic diversity to ascertain which are the driving forces of community assembly (e.g., habitat filtering vs. competition; e.g., Santos et al., 2016). Another interesting and related topic is the study of the biodiversity-ecosystem functioning relationship; island-mainland comparisons can also be useful for understanding how systems with different species richness and trait diversity can provide the basic ecosystem services on which humans depend.

Research conducted in Macaronesia has been pivotal in understanding island mutualistic interactions. Further studies on interaction networks will shed new light onto how biotic interactions affect community assembly, immigration, and extinction on islands, and on how alien species become integrated into the receptive communities and impact species interactions. Further studies from other archipelagos will also confirm whether the network patterns found for the Macaronesian islands are general or rather idiosyncratic (first comparisons with the Galápagos suggest these patterns are not general). Evaluating how such patterns may have influenced colonisation/extinction dynamics or speciation rates are prominent avenues that might change our understanding of island biogeography (Nogales et al., 2016).

Some of the most pressing questions in current research agendas are linked to the impact of global change on biodiversity patterns and processes as well as on human well-being. Such efforts are devoted to developing management strategies that can safeguard biodiversity and ecosystem services (Butchart et al., 2010). The relatively well-known history of human settlement across the islands and associated land-use transformations aids in assessing the relative impacts of environmental (pre)historical, demographic, and socioeconomic changes on current island biodiversity (see for instance: Nogué et al., 2013, 2017, 2021; Norder et al., 2020). Alien species constitute one of the most important threats island biotas face (Russell and Kueffer, 2019).
The simplified nature of island biotas might be essential for understanding how newly arrived species establish and affect existing species and ecosystems, and the implications of these novel species in conservation strategies. However, the precise impacts of novel native-alien interactions on island biodiversity and ecosystem functioning are still unclear (Patiño et al., 2017). Indeed, Lundgren et al. (2020) found that alien mammalian herbivores seem to have replaced some ecological functions that would otherwise be lost through the anthropogenic extinction of native species, a pattern that might not be extended to all island communities (e.g., Sobral et al., 2016). Long-term ecological data (see Van Leeuwen et al., 2005; Nogué et al., 2017) provide essential clues to disentangle the colonisation status of insular species and will contribute to progress in this research agenda.

\section{CONCLUSION}

Macaronesia has played a crucial role in the development of island biology. Research contributions in this region provide insights into ecological and evolutionary theories tested for other archipelagos (e.g., the General Dynamic Model of oceanic island biogeography, and its subsequent updates). Furthermore, political, scientific and social initiatives launched in Macaronesia to improve conservation practices and public awareness can be implemented in other regions, to assure the maintenance of biodiversity. However, knowledge of Macaronesia diversity is far from complete, and it is essential to continue gathering reliable data about species distribution to understand the relative importance of spatial, historical and ecological processes. Therefore, initiatives like long-term diversity studies need to be continued in Macaronesia, to obtain high quality data that will allow to widen knowledge of island biology in general.

\section{DEDICATION}

This article is dedicated to the memory of our co-author, Ana I. Neto. May she rest in peace.

\section{AUTHOR CONTRIBUTIONS}

MF led the manuscript writing, with significant contributions from AMCS, JP, SN, AT, PB, and HS. IRA led the subterranean biology group composed of $\mathrm{PB}, \mathrm{PC}, \mathrm{PO}, \mathrm{MA}$, and AM. RH led the marine biology group: AN, SÁ, and GM. AMCS led the community ecology group: JF-P, PB, and FR. PB led the biological conservation group composed of AG and RV. JP led the evolution group, comprising JCI, MR, HS, AVan, MA, and SG. MF led the freshwater biology group: PR and VG. AT led the plant-animal interaction and long-distance dispersal group: $\mathrm{MN}$ and AVal. MF led the biological invasion group: ML-D, LS, and MN. PB led the macroecology group, aided by PC. SN led the palaeobiology group: SÁ, JF-P, LN, and JR. All authors contributed to the drafts and gave final approval for publication. 


\section{FUNDING}

This research has been partially funded by the project REMEDINAL TECM (S2018/EMT- 4338). MF was funded by the Conselho Nacional de Desenvolvimento Científico e Tecnológico-CNPq (401045/2014-5) programme "Ciência sem Fronteiras," and the University of Alcalá, being currently funded by the Universidad Autónoma de Madrid. MF is also grateful to the project ClimaRiskinPond (PID2019104580GA-I00/AEI/10.13039/501100011033) funded by the Spanish Ministry of Science and Innovation. PB is grateful to the projects MACDIV (FCT-PTDC/BIABIC/0054/2014) and MOMENTOS (FCT-PTDC/BIA-BIC/5558/2014), funded by the Portuguese "Fundação para a Ciência e a Tecnologia, I.P” (FCT). AMCS and JP were supported by a Juan de la Cierva-Incorporación Fellowship (IJCI-2014-19502 and IJCI-2014-19691, respectively) funded by the Spanish "Ministerio de Ciencia, Innovación y Universidades." AMCS was additionally supported by a Marie Curie Intra-European Fellowship (IEF 331623 "COMMSTRUCT"), and by FCT (contract CEEIND/03425/2017). JP was additionally supported by a Ramón y Cajal Programme (RYC-2016-20506) and a Marie Skłodowska-Curie COFUND, Researchers' Night and Individual Fellowships Global (MSCA grant agreement no 747238, "UNISLAND"). SÁ acknowledges his IF/00465/2015 research contract funded by FCT (Portugal). SÁ, LS, PR, and VG were also funded by FEDER funds through the Operational Programme for Competitiveness Factors-COMPETE and by National Funds (FCT): UID/BIA/50027/2013 and POCI-010145-FEDER-006821. AM was supported by Marie SkłodowskaCurie Individual Fellowship (IF-EF), H2020 Programme of the EU, number 745530- "ANCAVE-Anchialine caves to understand evolutionary processes." Attendance by JF-P and LN at the Island Biology Conference 2016 was supported by the University of La Laguna through the "Ayudas a Proyectos Puente al Plan Estatal de I + D + I, Plan Propio de Investigación 2016." LN was supported by the European Union's Horizon 2020 Research and Innovation Programme under the Marie Skłodowska-Curie grant agreement no. 700952. IRA (SFRH/BPD/102804/2014), SG (SFRH/BPD/88854/2012), and RV (SFRH/BPD/79913/2011) were supported by post-doc grants from FCT, financed by The European Social Fund and the Human Potential Operational Programme, POPH/FSE. IRA, RV, and PR were funded by Portuguese funds through FCT, under the "Norma Transitória"DL57/2016/CP1375/CT0003, DL57/2016/CP1440/CT0002, and DL57/2016/ICETA/EEC2018/25, respectively. MR was

\section{REFERENCES}

Aigoin, D. A., Devos, N., Huttunen, S., Ignatov, M. S., Gonzalez-Mancebo, J. M., and Vanderpoorten, A. (2009). And if Engler was not completely wrong? Evidence for multiple evolutionary origins in the moss flora of Macaronesia. Evolution 63, 3248-3257. doi: 10.1111/j.1558-5646.2009.00 787.x

Albaladejo, R. G., Martín-Hernanz, S., Reyes-Betancort, J. A., Santos-Guerra, A., Olangua-Corral, M., and Abelardo, A. (2021). Reconstruction of the spatiotemporal diversification and ecological niche evolution of Helianthemum funded by Aga Khan Development Network and FCT (CVAgrobiodiversity/333111699). SG also thanks financial support from FCT/MCTES for the financial support to CESAM (UIDP/50017/2020 + UIDB/50017/2020), through national funds and in the scope of the framework contract foreseen in the numbers 4,5 , and 6 of the article 23, of the Decree-Law 57/2016, of August 29, changed by Law 57/2017, of July 19. AVal and MA were supported by the Ministerio de Economía y Competitividad (CGL2013-47429-P and PGC2018099772-B-I00, and CGL2016-80651-P, respectively). MA is also grateful to the Catalan Government (grant 2017SGR83). ML-D also acknowledges her current contract financed by Cabildo de Tenerife, Programme TF INNOVA 2016-21 (with MEDI and FDCAN Funds). RH beneffited from research funds provided by the EU ERA-Chair project EcoAqua (Grant \# 621341). JCI was funded by a research grant from the Spanish Ministry of Science, Innovation and Universities, and the European Regional Development Fund (Ref.: PGC2018-097575-B-I00) and by a regional GRUPIN grant from the Regional Government of Asturias (Ref.: IDI/2018/000151).

\section{ACKNOWLEDGMENTS}

The Island Biology Interest Group (IBIG, http://www. ibigbiology.com) is grateful to the organisers of the 2016 Island Biology Conference held in the Azores for promoting the symposium that led to this manuscript. We thank Joaquin Hortal for useful comments on an early version of the manuscript, and also Guido Jones for his language editing funded by the Cabildo de Tenerife, under the TFinnova Programme supported by MEDI and FDCAN funds. We are grateful to Salvador de la Cruz and Elena Morales for extracting updated information from the Biodiversity Data Bank of the Canary Islands. We also thank Ricardo Ramalho (Cardiff University) for fruitful discussions on the geological age of the Cabo Verde islands. This manuscript is a contribution by the INCT in Ecology, Evolution and Biodiversity Conservation funded by MCTIC/CNPq/FAPEG (grant 465610/2014-5).

\section{SUPPLEMENTARY MATERIAL}

The Supplementary Material for this article can be found online at: https://www.frontiersin.org/articles/10.3389/fevo.2021. 718169/full\#supplementary-material

(Cistaceae) in the Canary Islands using genotyping-by-sequencing data. Ann. Bot. 127, 597-611. doi: 10.1093/aob/mcaa090

Alcover, J. A., Pieper, H., Pereira, F., and Rando, J. C. (2015). Five new extinct species of rails (Aves: Gruiformes: Rallidae) from the Macaronesian Islands (North Atlantic Ocean). Zootaxa 4057, 151-190. doi: 10.11646/zootaxa.4057.2.1 Amorim, I. R. (2005). Colonization and Diversification on Oceanic Islands: Forest Tarphius and Cave Dwelling Trechus Beetles of the Azores. Ph.D. Dissertation. Los Angeles, CA: University of California.

Amorim, I. R., Emerson, B. C., Borges, P. A. V., and Wayne, R. K. (2012). Phylogeography and molecular phylogeny of Macaronesian Island Tarphius 
(Coleoptera: zopheridae): why are there so few species in the Azores? J. Biogeogr. 39, 1583-1595. doi: 10.1111/j.1365-2699.2012.02721.x

Ancochea, E., Hernán, F., Huertas, M. J., and Brändle, J. L. (2012). A basic radial dike swarm of Boa Vista (Cape Verde Archipelago); its significance in the evolution of the Island. J. Volcanol. Geoth. Res. 243, 24-37. doi: 10.1016/j. jvolgeores.2012.06.029

Ancochea, E., Huertas, M. J., Hernán, F., and Brändle, J. L. (2010). Volcanic evolution of São Vicente, Cape Verde Islands: the Praia Grande landslide. J. Volcanol. Geoth. Res. 198, 143-157. doi: 10.1016/j.jvolgeores.2010. 08.016

Ancochea, E., Huertas, M. J., Hernán, F., Brändle, J. L., and Alonso, M. (2015). Structure, composition and age of the small islands of Santa Luzia, Branco and Raso (Cape Verde Archipelago). J. Volcanol. Geoth. Res. 302, 257-272. doi: 10.1016/j.jvolgeores.2015.07.015

Anderson, C. L., Channing, A., and Zamuner, A. B. (2009). Life, death and fossilization on Gran Canaria-implications for Macaronesian biogeography and molecular dating. J. Biogeogr. 36, 2189-2201. doi: 10.1111/j.1365-2699. 2009.02222.x

Antonelli, A., Zizka, A., Carvalho, F. A., Scarhn, R., Bacon, C. D., Silvestro, D., et al. (2018). Amazonia is the primary source of Neotropical biodiversity. Proc. Natl. Acad. Sci. U.S.A. 115, 6034-6039. doi: 10.1073/pnas.171381 9115

Aranda, S. C., Gabriel, R., Borges, P. A. V., Santos, A. M. C., Azevedo, E. B., Patiño, J., et al. (2014). Geographical, temporal and environmental determinants of bryophyte species richness in the Macaronesian Islands. PLoS One 9:e101786. doi: 10.1371/journal.pone. 0101786

Aranda, S. C., Gabriel, R., Borges, P. A. V., Santos, A. M. C., Hortal, J., Baselga, A., et al. (2013). How do different dispersal modes shape the species-area relationship? Evidence for between-group coherence in the Macaronesian flora. Glob. Ecol. Biogeogr. 22, 483-493. doi: 10.1111/geb.12008

Arechavaleta, M., Rodríguez, S., Zurita, N., and García, A. (2010). Lista de Especies Silvestres de Canarias. Hongos, Plantas y Animales Terrestres 2009. Santa Cruz de Tenerife: Gobierno de Canarias.

Arechavaleta, M., Zurita, N., Marrero, M. C., and Martín, J. L. (2005). Lista Preliminar de Especies Silvestres de Cabo Verde (Hongos, Plantas y Animales Terrestres). Santa Cruz de Tenerife: Gobierno de Canarias.

Arnedo, M. A., Oromí, P., Múrria, C., Macías-Hernández, N., and Ribera, C. (2007). The dark side of an island radiation: systematics and evolution of troglobitic spiders of the genus Dysdera (Araneae, Dysderidae) in the Canary Islands. Invertebr. Syst. 21, 623-660. doi: 10.1071/IS07015

Ávila, S. P. (2013). "Unravelling the patterns and processes of evolution of marine life in oceanic islands: a global framework," in The Climate Change Perspectives from the Atlantic: Past, Present and Future, eds J. M. Fernández-Palacios, L. De Nascimento, J. C. Hernández, S. Clemente, A. González, and J. P. Díaz-González (Tenerife: Universidad de La Laguna), 95-125.

Ávila, S. P., Cordeiro, R., Madeira, P., Silva, L., Medeiros, A., Rebelo, A. C., et al. (2018). Global change impacts on large-scale biogeographic patterns of marine organisms on Atlantic oceanic islands. Mar. Pollut. Bull. 126, 101-112. doi: 10.1016/j.marpolbul.2017.10.087

Ávila, S. P., Goud, J., and Martins, A. M. F. (2012). Patterns of diversity of the Rissoidae (Mollusca: gastropoda) in the Atlantic and the Mediterranean Region. Sci. World J. 2012:164890. doi: 10.1100/2012/164890

Ávila, S. P., Marques Da Silva, C., Schiebel, R., Cecca, F., Backeljau, T., and De Frias Martins, A. M. (2009). How did they get here? The biogeography of the marine molluscs of the Azores. Bull. Soc. Géol. Fr. 180, 295-307. doi: 10.2113/gssgfbull. 180.4.295

Ávila, S. P., Melo, C., Berning, B., Cordeiro, R., Landau, B., and da Silva, C. M. (2016). Persististrombus coronatus (Mollusca: strombidae) in the early Pliocene of Santa Maria Island (Azores: NE Atlantic): palaeoecology, palaeoclimatology and palaeobiogeographic implications on the NE Atlantic Molluscan Biogeographical Provinces. Palaeogeogr. Palaeoclimatol. Palaeoecol. 441, 912-923. doi: 10.1016/j.palaeo.2015.10.043

Ávila, S. P., Melo, C., Berning, B., Sá, N. B. F., Quartau, R., Rijsdijk, K. F., et al. (2019). Towards a "Sea-Level Sensitive" dynamic model: impact of island ontogeny and glacio-eustasy on global patterns of marine island biogeography. Biol. Rev. 94, 1116-1142. doi: 10.1111/brv.12492

Ávila, S. P., Melo, C., Silva, L., Ramalho, R., Quartau, R., Hipólito, A., et al. (2015a). A review of the MIS 5e highstand deposits from Santa Maria Island (Azores, NE
Atlantic): palaeobiodiversity, palaeoecology and palaeobiogeography. Quat. Sci. Rev. 114, 126-148. doi: 10.1016/j.quascirev.2015.02.012

Ávila, S. P., Ramalho, R., Habermann, J., Quartau, R., Kroh, A., Berning, B., et al. (2015b). Palaeoecology, taphonomy, and preservation of a lower Pliocene shell bed (coquina) from a volcanic oceanic Island (Santa Maria Island, Azores, NE Atlantic Ocean). Palaeogeogr. Palaeoclimatol. Palaeoecol. 430, 57-73. doi: 10.1016/j.palaeo.2015.04.015

Azevedo, J. M. M., and Portugal Ferreira, M. R. (2006). The volcanotectonic evolution of Flores Island, Azores (Portugal). J. Volcanol. Geoth. Res. 156, 90-102. doi: 10.1016/j.jvolgeores.2006.03.011

Baptista, L., Santos, A. M., Pilar Cabezas, M., Cordeiro, R., Melo, C., and Ávila, S. P. (2019). Intertidal or subtidal/circalittoral species: which appeared first? A phylogenetic approach to the evolution of non-planktotrophic species in Atlantic Archipelagos. Mar. Biol. 166:88. doi: 10.1007/s00227-019-3536-y

Bell, B. D. (2001). Removal of rabbits from Deserta Grande Island, Madeira Archipelago. Arquipélago Life Mar. Sci. Suppl. 2(Part B), 115-117.

Biodiversity Data Bank of the Canary Islands (2021). Government of the Canary Islands. Available online at: https://www.biodiversidadcanarias.es/biota/?lang= en (accessed September 1, 2021).

Bloor, P., Kemp, S. J., and Brown, R. P. (2008). Recent volcanism and mitochondrial DNA structuring in the lizard Gallotia atlantica from the island of Lanzarote. Mol. Ecol. 17, 854-866. doi: 10.1111/j.1365-294X.2007.03575.x

Boieiro, M., Matthews, T. J., Rego, C., Crespo, L., Aguiar, C. A. S., Cardoso, P., et al. (2018). A comparative analysis of terrestrial arthropod assemblages from a relict forest unveils historical extinctions and colonization differences between two oceanic islands. PLoS One 13:e0195492. doi: 10.1371/journal.pone.0195492

Borda-de-Água, L., Whittaker, R., Cardoso, P., Rigal, F., Santos, A. M. C., Amorim, I., et al. (2017). Dispersal ability determines the scaling properties of species abundance distributions: a case study using arthropods from the Azores. Sci. Rep. 7:3899. doi: 10.1038/s41598-017-04126-5

Borges, P. A. V., Abreu, C., Aguiar, A. M. F., Carvalho, P., Jardim, R., Melo, I., et al. (2008). A List of the Terrestrial Fungi, Flora and Fauna of Madeira and Selvagens Archipelagos. Azores: Direcção Regional do Ambiente da Madeira and Universidade dos Açores, Funchal and Angra do Heroísmo.

Borges, P. A. V., and Hortal, J. (2009). Time, area and isolation: factors driving the diversification of Azorean arthropods. J. Biogeogr. 36, 178-191. doi: 10.1111/j. 1365-2699.2008.01980.x

Borges, P. A. V., Cardoso, P., Amorim, I. R., Pereira, F., Constância, J. P., Nunes, J. C., et al. (2012). Volcanic caves: priorities for conserving the Azorean endemic troglobiont species. Int. J. Speleol. 41, 101-112. doi: 10.5038/1827-806X.41.1.11

Borges, P. A. V., Cardoso, P., Kreft, H., Whittaker, R., Fattorini, S., Emerson, B., et al. (2018). A Global Island Monitoring Scheme (GIMS): a proposal for the long-term coordinated survey and monitoring of native island forest biota. Biodivers. Conserv. 27, 2567-2586. doi: 10.1007/s10531-018-1553-7

Borges, P. A. V., Costa, A., Cunha, R., Gabriel, R., Gonçalves, V., Martins, A. F., et al. (2010). A List of the Terrestrial and Marine Biota From the Azores. Cascais: Princípia.

Borges, P. A. V., Santos, A. M. C., Elias, R. B., and Gabriel, R. (2019). "The Azores archipelago: biodiversity erosion and conservation biogeography," in The Encyclopedia of the World's Biomes -Earth Systems and Environmental Sciences, ed. S. A. Elias (Amsterdam: Elsevier), 1-18, Reference Module in Earth Systems and Environmental Sciences.

Borregaard, M. K., Amorim, I. R., Borges, P. A. V., Cabral, J. S., Fernández-Palacios, J. M., Field, R., et al. (2017). Oceanic island biogeography through the lens of the General Dynamic Model: assessment and prospect. Biol. Rev. 92, 830-853. doi: 10.1111/brv.12256

Britton-Davidian, J., Catalan, J., Ramalhinho, M. G., Ganem, G., Auffray, J. C., Capela, R., et al. (2000). Rapid chromosomal evolution in island mice. Nature 403:158. doi: $10.1038 / 35003116$

Brooke, M., Gregory, L., Geraldes, P., Castelló, L., Donald, P. F., Melo, T., et al. (2020). Lessons and surprises from an inter-island re-introduction of the critically endangered Raso lark Alauda razae of Cape Verde. Parks 26, 47-58.

Brown, R. P., Hoskisson, P. A., Welton, J. H., and Baez, M. (2006). Geological history and within-island diversity: a debris avalanche and the Tenerife lizard Gallotia galloti. Mol. Ecol. 15, 3631-3640. doi: 10.1111/j.1365-294X.2006. 03048.x

Buchaca, T., Skov, T., Amsinck, S. L., Gonçalves, V., Azevedo, J. M. N., Andersen, T. J., et al. (2011). Rapid ecological shift following piscivorous fish introduction 
to increasingly eutrophic and warmer Lake Furnas (Azores Archipelago, Portugal): a paleoecological approach. Ecosystems 14, 458-477. doi: 10.1007/ s10021-011-9423-0

Burunat-Pérez, G., Suárez-Rancel, M., and Molina-Borja, M. (2018). Predator avoidance training of the endangered lizard from El Hierro (Canary Islands): a new management strategy before reintroduction into the wild. Behav. Processes 157, 192-198. doi: 10.1016/j.beproc.2018.09.010

Butchart, S. H., Walpole, M., Collen, B., Van Strien, A., Scharlemann, J. P., Almond, R. E., et al. (2010). Global biodiversity: indicators of recent declines. Science 328, 1164-1168. doi: 10.1126/science.1187512

Cacabelos, E., Martins, G. M., Thompson, R., Prestes, A. C. L., Azevedo, J. M. N., and Neto, A. I. (2016a). Material type and roughness influence structure of inter-tidal communities on coastal defenses. Mar. Ecol. 37, 801-812. doi: 10. $1111 /$ maec. 12354

Cacabelos, E., Martins, G. M., Thompson, R., Prestes, A. C. L., Azevedo, J. M. N., and Neto, A. I. (2016b). Factors limiting the establishment of canopy-forming algae on artificial structures. Estuar. Coast. Shelf Sci. 181, 277-283. doi: 10.1016/ j.ecss.2016.08.036

Calado, H., Bragagnolo, C., Silva, S., and Vergílio, M. (2016). Adapting environmental function analysis for management of protected areas in small islands-case of Pico Island (the Azores). J. Environ. Manage. 171, 231-242. doi: 10.1016/j.jenvman.2016.02.015

Cameron, R. A. D., Triantis, K. A., Parent, C. E., Guilhaumon, F., Alonso, M. R., Ibáñez, M., et al. (2013). Snails on oceanic islands: testing the general dynamic model of oceanic island biogeography using linear mixed effect models. J. Biogeogr. 40, 117-130. doi: 10.1111/j.1365-2699.2012.02781.x

Cardoso, P., Arnedo, M. A., Triantis, K. A., and Borges, P. A. V. (2010). Drivers of diversity in Macaronesian spiders and the role of species extinctions. J. Biogeogr. 37, 1034-1046. doi: 10.1111/j.1365-2699.2009.02264.x

Cardoso, P., Borges, P. A. V., Triantis, K., Ferrández, M. A., and Martín, J. L. (2011). Adapting the IUCN red listing criteria for invertebrates. Biol. Conserv. 144, 2432-2440. doi: 10.1016/j.biocon.2012.02.011

Cardoso, P., Rigal, F., Fattorini, S., Terzopoulou, S., and Borges, P. A. V. (2013). Integrating landscape disturbance and indicator species in conservation studies. PLoS One 8:e63294. doi: 10.1371/journal.pone.0063294

Carine, M. A., and Schaefer, H. (2010). The Azores diversity enigma: why are there so few Azorean endemic flowering plants and why are they so widespread? J. Biogeogr. 37, 77-89. doi: 10.1111/j.1365-2699.2009.02181.x

Carine, M. A., Jones, K., Moura, M., Maciel, M. G. B., Rumsey, F. J., and Schaefer, H. (2012). Putting biogeography's cart back behind taxonomy's horse: a response to Triantis et al. J. Biogeogr. 39, 1184-1187. doi: 10.1111/j.1365-2699.2012. 02736.x

Carine, M. A., Russell, S. J., Santos-Guerra, A., and Francisco-Ortega, J. (2004). Relationships of the Macaronesian and Mediterranean floras: molecular evidence for multiple colonizations into Macaronesia and back-colonization of the continent in Convolvulus (Convolvulaceae). Am. J. Bot. 91, 1070-1085. doi: 10.3732/ajb.91.7.1070

Carine, M. A., Santos-Guerra, A., Guma, I. R., and Reyes-Betancort, J. A. (2010). "Endemism and evolution of the Macaronesian flora," in Beyond cladistics: the branching of a paradigm, eds D. M. Williams and S. K. Knapp (Berkeley, CA: University of California Press), 101-124.

Carranza, S., Arnold, E. N., Mateo, J. A., and López-Jurado, L. F. (2000). Longdistance colonization and radiation in gekkonid lizards, Tarentola (Reptilia: Gekkonidae), revealed by mitochondrial DNA sequences. Proc. R. Soc. Lond. B 267, 637-649. doi: 10.1098/rspb.2000.1050

Carvalho, J. C., Cardoso, P., Rigal, F., Triantis, K., and Borges, P. A. V. (2015). Modeling directional spatio-temporal processes in island biogeography. Ecol. Evol. 5, 4671-4682. doi: 10.1002/ece3.1632

Caujapé-Castells, J. (2011). "Jesters, red queens, boomerangs and surfers: a molecular outlook on the diversity of the Canarian endemic flora," in The Biology of Island Floras, eds D. Bramwell and J. Caujapé-Castells (New York, NY: Cambridge University Press), 284-324.

Caujapé-Castells, J., García-Verdugo, C., Marrero-Rodríguez, A., FernándezPalacios, J. M., Crawford, D. J., and Mort, M. E. (2017). Island ontogenies, syngameons, and the origins and evolution of genetic diversity in the Canarian endemic flora. Perspect. Plant Ecol. 27, 9-22. doi: 10.1016/j.ppees.2017.03.003

Chainho, P., Fernandes, A., Amorim, A., Ávila, S. P., Canning-Clode, J., Castro, J. J., et al. (2015). Non-indigenous species in Portuguese coastal areas, coastal lagoons, estuaries and islands. Estuar. Coast. Shelf Sci. 167, 199-211. doi: 10. 1016/j.ecss.2015.06.019

Chmatal, L., Gabriel, S. I., Mitsainas, G. P., Martinez-Vargas, J., Ventura, J., Searle, J. B., et al. (2014). Centromere strength provides the cell biological basis for meiotic drive and karyotype evolution in mice. Curr. Biol. 24, 2295-2300. doi: 10.1016/j.cub.2014.08.017

Chua, M. A. H., and Aziz, S. A. (2018). Into the light: atypical diurnal foraging activity of Blyth's horseshoe bat, Rhinolophus lepidus (Chiroptera: Rhinolophidae) on Tioman Island, Malaysia. Mammalia 83, 78-83. doi: 10. 1515/mammalia-2017-0128

Clegg, S. (2010). "Evolutionary changes following island colonization in birds. Empirical insights into the roles of microevolutionary processes," in The Theory of Island Biogeography Revisited, eds L. B. Losos and R. E. Ricklefs (Princeton, NJ: Princeton University Press), 293-325.

Condamine, F. L., Leslie, A. B., and Antonelli, A. (2017). Ancient islands acted as refugia and pumps for conifer diversity. Cladistics 33, 69-92. doi: 10.1111/cla. 12155

Contreras-Díaz, H. G., Moya, O., Oromí, P., and Juan, C. (2007). Evolution and timescale diversification of the forest and hypogean ground-beetle radiation of the genus Trechus in the Canary Islands. Mol. Phylogenet. Evol. 42, 687-699. doi: 10.1016/j.ympev.2006.10.007

Cordeiro, R., Borges, J. P., Martins, A. M. F., and Ávila, S. P. (2015). Checklist of the littoral gastropods (Mollusca: gastropoda) from the Archipelago of the Azores (NE Atlantic). Biodivers. J. 6, 855-900.

Cornu, M. N., Paris, R., Doucelance, R., Bachélery, P., Bosq, C., Auclair, D., et al. (2021). Exploring the links between volcano flank collapse and the magmatic evolution of an ocean island volcano: Fogo, Cape Verde. Sci. Rep. 11:17478. doi: 10.1038/s41598-021-96897-1

Costa, A. C. G., Hildenbrand, A., Marques, F. O., Sibrant, A. L. R., and Santos de Campos, A. (2015). Catastrophic flank collapses and slumping in Pico Island during the last $130 \mathrm{kyr}$ (Pico-Faial ridge, Azores Triple Junction). J. Volcanol. Geoth. Res. 302, 33-46. doi: 10.1016/j.jvolgeores.2015.06.008

Costa, H., Bettencourt, M. J., Silva, C. M. N., Teodósio, J., Gil, A., and Silva, L. (2013). "Invasive alien plants in the Azorean protected areas: invasion status and mitigation actions," in Plant Invasions in Protected Areas. Invading Nature - Springer Series in Invasion Ecology, Vol. 7, eds L. C. Foxcroft, D. M. Richardson, P. Pyšek, and P. Genovesi (Dordrecht: Springer), 375-394.

Cox, S. C., Carranza, S., and Brown, R. P. (2010). Divergence times and colonization of the Canary Islands by Gallotia lizards. Mol. Phylogenet. Evol. 56, 747-757. doi: 10.1016/j.ympev.2010.03.020

Cruz, A., Benedicto, J., and Gil, A. (2011). Socio-economic benefits of Natura 2000 in Azores Islands - a case study approach on the ecosystem services provided by a special protected area. J. Coast. Res. 64, 1955-1959.

Dawson, M. N. (2016). Island and island-like marine environments. Glob. Ecol. Biogeogr. 25, 831-846. doi: 10.1111/geb.12314

de Nascimento, L., Nogué, S., Criado, C., Ravazzi, C., Whittaker, R. J., Willis, K. J., et al. (2016). Reconstructing Holocene vegetation on the island of Gran Canaria before and after human colonization. Holocene 26, 113-125. doi: 10. $1177 / 0959683615596836$

de Nascimento, L., Willis, K. J., Fernández-Palacios, J. M., Criado, C., and Whittaker, R. J. (2009). The long-term ecology of the lost forests of La Laguna, Tenerife (Canary Islands). J. Biogeogr. 36, 499-514. doi: 10.1111/j.1365-2699. 2008.02012.x

del Arco-Aguilar, M. J., Gonzalez-Gonzalez, R., Garzon-Machado, V., and PizarroHernandez, B. (2010). Actual and potential natural vegetation on the Canary Islands and its conservation status. Biodivers. Conserv. 19, 3089-3140. doi: 10.1007/s10531-010-9881-2

Desamoré, A., Laenen, B., González-Mancebo, J. M., Jaén Molina, R., Bystriakova, N., Martinez-Klimova, E., et al. (2012). Inverted patterns of genetic diversity in continental and island populations of the heather Erica scoparia sl. J. Biogeogr. 39, 574-584. doi: 10.1111/j.1365-2699.2011.02622.x

Diamond, J. M. (1970). Ecological consequences of island colonization by southwest Pacific birds, I. Types of niche shifts. Proc. Natl. Acad. Sci. U.S.A. 67, 529-536. doi: 10.1073/pnas.67.2.529

Duda, T. F., and Rolán, E. (2005). Explosive radiation of Cape Verde Conus, a marine species flock. Mol. Ecol. 14, 267-272. doi: 10.1111/j.1365-294X.2004. 02397.x 
Dupont, Y. L., and Skov, C. (2004). Influence of geographical distribution and floral traits on species richness of bees (Hymenoptera: apoidea) visiting Echium species (Boraginaceae) of the Canary Islands. Int. J. Plant. Sci. 165, 377-386. doi: $10.1086 / 382806$

Dupont, Y. L., Hansen, D. M., Valido, A., and Olesen, J. M. (2004). Impact of introduced honey bees on natural pollination interactions of the endemic Echium wildpretii (Boraginaceae) on Tenerife, Canary Islands. Biol. Conserv. 118, 301-311. doi: 10.1016/j.biocon.2003.09.010

Dyhr, C. T., and Holm, P. M. (2010). A volcanological and geochemical investigation of Boa Vista, Cape Verde Islands; 40Ar/39Ar geochronology and field constraints. J. Volcanol. Geoth. Res. 189, 19-32. doi: 10.1016/j.jvolgeores. 2009.10.010

Edwards, E. J., and Donoghue, M. J. (2013). Is it easy to move and easy to evolve? Evolutionary accessibility and adaptation. J. Exp. Bot. 64, 4047-4052.

Emerson, B. C. (2002). Evolution on oceanic islands: molecular phylogenetic approaches to understanding pattern and process. Mol. Ecol. 11, 95-966.

Emerson, B. C., Oromí, P., and Hewitt, G. M. (1999). MtDNA phylogeography and recent intra-island diversification among Canary Island Calathus beetles. Mol. Phylogenet. Evol. 13, 149-158. doi: 10.1006/mpev.1999.0644

Engler, A. (1879). Versuch Einer Entwicklungsgeschichte, Insbesondere der Florengebiete seit der Tertiärperiode: I. Die Extra-Tropischen Gebiete der Nördlichen Hemisphäre. Leipzig: W. Engelmann.

Engler, A. (1914). "Pflanzengeographie," in Kultur der Gegenwart, Ihre Entwicklung und ihre Ziele: Vierter Band: Abstammungslehre, Systematik. Paläontologie, Biogeographie, eds R. Hertwig and R. V. Wettstein (Leipzig: Teubner), 187-263

Faria, J., Martins, G. M., Pita, A., Ribeiro, P. A., Hawkins, S. J., Presa, P., et al. (2017). Disentangling the genetic and morphological structure of Patella candei complex in Macaronesia (NE Atlantic). Ecol. Evol. 7, 6125-6140. doi: 10.1002/ ece 3.3121

Fattorini, S., Rigal, F., Cardoso, P., and Borges, P. A. V. (2016). Using species abundance distribution models and diversity indices for biogeographical analyses. Acta Oecol. 70, 21-28. doi: 10.1016/j.actao.2015.11.003

Faurby, S., and Svenning, J.-C. (2016). Resurrection of the island rule: humandriven extinctions have obscured a basic evolutionary pattern. Am. Nat. 187, 812-820.

Fernandes, J. P., Guiomar, N., and Gil, A. (2015). Strategies for conservation planning and management of terrestrial ecosystems in small islands (exemplified for the Macaronesian Islands). Environ. Sci. Policy 51, 1-22. doi: 10.1016/j.envsci.2015.03.006

Fernández-Mazuecos, M., and Vargas, P. (2011). Historical isolation versus recent long-distance connections between Europe and Africa in bifid toadflaxes (Linaria sect. Versicolores). PLoS One 6:e22234. doi: 10.1371/journal.pone. 0022234

Fernández-Palacios, J. M. (2010). “The islands of Macaronesia," in Terrestrial Arthropods of Macaronesia. Biodiversity, Ecology and Evolution, eds A. R. M. Serrano, P. A. V. Borges, M. Boieiro, and P. Oromí (Lisboa: Sociedade Portuguesa de Entomología), 1-30.

Fernández-Palacios, J. M., and Whittaker, R. J. (2020). Early recognition by Ball and Hooker in 1878 of plant back-colonization (boomerang) events from Macaronesia to Africa. Front. Biogeogr. 12:e45375. doi: 10.21425/F5FBG45375

Fernández-Palacios, J. M., de Nascimento, L., Otto, R., Delgado, J. D., García-delRey, E., Arévalo, J. R., et al. (2011). A reconstruction of Palaeo-Macaronesia, with particular reference to the long-term biogeography of the Atlantic island laurel forests. J. Biogeogr. 38, 226-246. doi: 10.1111/j.1365-2699.2010. 02427.x

Fernández-Palacios, J. M., Rijsdijk, K. F., Norder, S. J., Otto, R., de Nascimento, L., Fernández-Lugo, S., et al. (2016). Towards a glacial-sensitive model of island biogeography. Glob. Ecol. Biogeogr. 25, 817-830. doi: 10.1111/geb.12320

Ferreira, M. T., Cardoso, P., Borges, P. A. V., Gabriel, R., de Azevedo, E. B., Reis, F., et al. (2016). Effects of climate change on the distribution of indigenous species in oceanic islands (Azores). Clim. Change 138, 603-615. doi: 10.1007/s10584016-1754-6

Förster, D. W., Gündüz, I., Nunes, A. C., Gabriel, S., Ramalhinho, M. G., Mathias, M. L., et al. (2009). Molecular insights into the colonization and chromosomal diversification of Madeiran house mice. Mol. Ecol. 18, 4477-4494. doi: 10.1111/ j.1365-294X.2009.04344

Frankham, R. (1997). Do island populations have less genetic variation than mainland populations? Heredity 78, 311-327. doi: 10.1038/hdy.1997.46
Freitas, R., Romeiras, M., Silva, L., Cordeiro, R., Madeira, P., González, J. Á, et al. (2019). Restructuring of the "Macaronesia" biogeographic unit: a marine multitaxon biogeographical approach. Sci. Rep. 9:15792. doi: 10.1038/s41598-01951786-6

Gabriel, S. I., Mathias, M. L., and Searle, J. B. (2015). Of mice and the Age of Discovery': the complex history of colonization of the Azorean archipelago by the house mouse (Mus musculus) as revealed by mitochondrial DNA variation. J. Evol. Biol. 28, 130-145. doi: 10.1111/jeb.12550

García-Maroto, F., Mañas-Fernández, A., Garrido-Cárdenas, J. A., Alonso, D. L., Guil-Guerrero, J. L., Guzman, B., et al. (2009). $\Delta 6$-Desaturase sequence evidence for explosive Pliocene radiations within the adaptive radiation of Macaronesian Echium (Boraginaceae). Mol. Phylogenet. Evol. 52, 563-574. doi: 10.1016/j.ympev.2009.04.009

García-Olivares, V., López, H., Patiño, J., Alvarez, N., Machado, A., Carracedo, J. C., et al. (2017). Evidence for mega-landslides as drivers of island colonisation. J. Biogeogr. 44, 1053-1064. doi: 10.1111/jbi.12961

García-Verdugo, C., Caujapé-Castells, J., and Monroy, P. (2019). How repeatable is microevolution on islands? Patterns of dispersal and colonization-related plant traits in a phylogeographical context. Ann. Bot. 123, 557-568. doi: 10.1093/aob/ mcy191

García-Verdugo, C., Sajeva, M., La Mantia, T., Harrouni, C., Msanda, F., and Caujapé-Castells, J. (2015). Do island plant populations really have lower genetic variation than mainland populations? Effects of selection and distribution range on genetic diversity estimates. Mol. Ecol. 24, 726-741. doi: 10.1111/mec.13060

Garcillán, P. P., and Ezcurra, E. (2011). Sampling procedures and species estimation: testing the effectiveness of herbarium data against vegetation sampling in an oceanic island. J. Veg. Sci. 22, 273-280. doi: 10.1111/j.1654-1103. 2010.01247.x

Gaspar, C., Gaston, K. J., Borges, P. A. V., and Cardoso, P. (2011). Selection of priority areas for arthropod conservation in the Azores archipelago. J. Insect Conserv. 15, 671-684. doi: 10.1007/s10841-010-9365-4

Geldmacher, J., Hoernle, K., van den Bogaard, P., Zankl, G., and Garbe-Schönberg, D. (2001). Earlier history of the $\geq 70$-Ma-old Canary hotspot based on the temporal and geochemical evolution of the Selvagen Archipelago and neighboring seamounts in the eastern North Atlantic. J. Volcanol. Geoth. Res. 11, 55-87. doi: 10.1016/S0377-0273(01)00220-7

Gil, A., Calado, H., Costa, L. T., Bentz, J., Fonseca, C., Lobo, A., et al. (2011). A methodological proposal for the development of Natura 2000 sites management plans. J. Coast. Res. 64, 1326-1330.

Gil, A., Ceia, R., Coelho, R., Teodósio, J., Sampaio, H., Veríssimo, C., et al. (2016b). The Priolo Atlas: a citizen science-based census initiative for supporting Pyrrhula murina habitat conservation and restoration policies in São Miguel Island (Azores, Portugal). Ecol. Eng. 86, 45-52.

Gil, A., Fonseca, C., and Benedicto-Royuela, J. (2017). Land cover trade-offs in small oceanic islands: a temporal analysis of Pico Island, Azores. Land Degrad. Dev. 29, 349-360. doi: 10.1002/ldr.2770

Gil, A., Vieira, C. P., Yu, Q., Lobo, A., and Calado, H. (2016a). Mapping the ecological structure in small islands - the case-study of S. Miguel Island (Archipelago of the Azores, Portugal). Environ. Eng. Manag. J. 15, 1593-1602.

Gonçalves, V., Ritter, C., Marques, H., Teixeira, D. N., and Raposeiro, P. M. (2021). Diatoms from small ponds and terrestrial habitats in Deserta Grande Island (Madeira Archipelago). Biodivers. Data J. 9, e59898. doi: 10.3897/BDJ.9.e59898

González-Castro, A., Traveset, A., and Nogales, M. (2012). Seed dispersal interactions in the Mediterranean Region: contrasting patterns between islands and mainland. J. Biogeogr. 39, 1938-1947. doi: 10.1111/j.1365-2699.2012.02 693.x

González-Mancebo, J. M., Dirkse, G. M., Patiño, J., Romaguera, F., Werner, O., Ros, R. M., et al. (2012). Applying the IUCN Red List criteria to small-sized plants on oceanic islands: conservation implications for threatened bryophytes in the Canary Islands. Biodivers. Conserv. 21, 3613-3636. doi: 10.1007/s10531012-0385-0

Grant, P. R., and Grant, B. R. (2006). Evolution of character displacement in Darwin's Finches. Science 313, 224-226. doi: 10.1126/science.1128374

Grant, P. R., Smith, N. M., Grant, B. R., Abbott, I. J., and Abbott, L. K. (1975). Finch numbers, owl predation and plant dispersal on Isla Daphne Major, Galápagos. Oecologia 19, 239-257. doi: 10.1007/BF00345308 
Hachich, N. F., Bonsall, M. B., Arraut, E. M., Barneche, D. R., Lewinsohn, T. M., and Floeter, S. R. (2015). Island biogeography: patterns of marine shallow-water organisms in the Atlantic Ocean. J. Biogeogr. 42, 1871-1882. doi: 10.1111/jbi. 12560

Heads, M. (2010). Old taxa on young islands: a critique of the use of island age to date island-endemic clades and calibrate phylogenies. Syst. Biol. 60, 204-218. doi: 10.1093/sysbio/syq075

Heleno, R. H., Olesen, J. M., Nogales, M., Vargas, P., and Traveset, A. (2013). Seed dispersal networks in the Galápagos and the consequences of alien plant invasions. Proc. R. Soc. B 280:20122112. doi: 10.1098/rspb.2012.2112

Heleno, R., and Vargas, P. (2015). How do islands become green? Glob. Ecol. Biogeogr. 24, 518-526. doi: 10.1111/geb.12273

Heleno, R., Lacerda, I., Ramox, J. A., and Memmott, J. (2010). Evaluation of restoration effectiveness: community response to the removal of alien plants. Ecol. Appl. 20, 1191-1203.

Henriques, D. S. G., Ah-Peng, C., and Gabriel, R. (2017). Structure and applications of BRYOTRAIT-AZO, a trait database for Azorean bryophytes. Cryptogam. Bryol. 38, 137-152. doi: 10.7872/cryb/v38.iss2.2017.137

Hernández-Teixidor, D., Díaz-Luis, N., Medina, F. M., and Nogales, M. (2019). First record of geckos visiting flowers in the Palaearctic Ecozone. Curr. Zool. 66, 447-448. doi: 10.1093/cz/zoz051

Hervías-Parejo, S., Heleno, R., Rumeu, B., Guzmán, B., Vargas, P., Olesen, J. M., et al. (2019). Small size does not restrain frugivory and seed dispersal across the evolutionary radiation of Galápagos lava lizards. Curr. Zool. 65, 353-361. doi: $10.1093 / \mathrm{cz} /$ zoy066

Holm, P. M., Wilson, J. R., Christensen, B. P., Hansen, L., Hansen, S. L., Hein, K. M., et al. (2006). Sampling the Cape Verde mantle plume: evolution of melt compositions on Santo Antão, Cape Verde Islands. J. Petrol. 47, 145-189. doi: 10.1093/petrology/egi071

Hughes, S. J., and Malmqvist, B. (2005). Atlantic island freshwater ecosystems: challenges and considerations following the EU Water Framework Directive. Hydrobiologia 544, 289-297. doi: 10.1007/s10750-005-1695-y

Hutsemékers, V., Szövényi, P., Shaw, A. J., González-Mancebo, J. M., Muñoz, J., and Vanderpoorten, A. (2011). Oceanic islands are not sinks of biodiversity in spore-producing plants. Proc. Natl. Acad. Sci. U.S.A. 108, 18989-18994. doi: $10.1073 /$ pnas.1109119108

Illera, J. C., Rando, J. C., Richardson, D. S., and Emerson, B. C. (2012). Age, origins and extinctions of the avifauna of Macaronesia: a synthesis of phylogenetic and fossil information. Quat. Sci. Rev. 50, 14-22. doi: 10.1016/j.quascirev.2012. 07.013

Illera, J. C., Spurgin, L. G., Rodriguez-Exposito, E., Nogales, M., and Rando, J. C. (2016). What are we learning about speciation and extinction from the Canary Islands? Ardeola 63, 15-33. doi: 10.13157/arla.63.1.20 16.rpl

IUCN Standards and Petitions Subcommittee (2017). Guidelines for Using the IUCN Red List Categories and Criteria. Version 13. Prepared by the Standards and Petitions Subcommittee. Available online at: http://www.iucnredlist.org/ documents/RedListGuidelines.pdf (accessed December 1, 2017).

Johnson, M. E., Ramalho, R. S., Baarli, B. G., Cachão, M., da Silva, C. M., Mayoral, E. J., et al. (2014). Miocene-Pliocene rocky shores on São Nicolau (Cape Verde Islands): contrasting windward and leeward biofacies on a volcanically active oceanic island. Palaeogeogr. Palaeoclimatol. Palaeoecol. 395, 131-143. doi: 10. 1016/j.palaeo.2013.12.028

Jones, K. E., Reyes-Betancort, J. A., Hiscock, S. J., and Carine, M. A. (2014). Allopatric diversification, multiple habitat shifts, and hybridization in the evolution of Pericallis (Asteraceae), a Macaronesian endemic genus. Am. J. Bot. 101, 637-651. doi: 10.3732/ajb.1300390

Jønsson, K. A., and Holt, B. G. (2015). Islands contribute disproportionately high amounts of evolutionary diversity in passerine birds. Nat. Commun. 6:8538. doi: $10.1038 /$ ncomms 9538

Jorgensen, T. H., and Olesen, J. M. (2001). Adaptive radiation of island plants: evidence from Aeonium (Crassulaceae) of the Canary Islands. Perspect. Plant Ecol. 4, 29-42. doi: 10.1078/1433-8319-00013

Kondraskov, P., Schütz, N., Schüßler, C., de Sequeira, M. M., Guerra, A. S., Caujapé-Castells, J., et al. (2015). Biogeography of Mediterranean hotspot biodiversity: re-evaluating the 'Tertiary Relict' hypothesis of Macaronesian laurel forests. PLoS One 10:e132091. doi: 10.1371/journal.pone.0132091
Laenen, B., Désamoré, A., Devos, N., Shaw, A. J., González-Mancebo, J. M., Carine, M. A., et al. (2011). Macaronesia: a source of hidden genetic diversity for post-glacial recolonization of Western Europe in the leafy liverwort Radula lindenbergiana. J. Biogeogr. 38, 631-639. doi: 10.1111/j.1365-2699.2010.02440.x

Lamelas-López, L., Borges, P. A. V., Serrano, L., Gonçalves, V., and Florencio, M. (2021). Biodiversity patterns of macroinvertebrate assemblages in natural and artificial lentic waters on an oceanic island. Front. Ecol. Evol. 8:528. doi: $10.3389 /$ fevo. 2020.605176

Leo, M., Steinbauer, M. J., Borges, P. A. V., de Azevedo, E. B., Gabriel, R., Schaefer, H., et al. (2021). Dispersal syndromes are poorly associated with climatic niche differences in the Azorean seed plants. J. Biogeogr. 48, 2275-2285. doi: 10.1111/ jbi. 14151

Lobo, J., and Borges, P. A. V. (2010). "The provisional status of arthropod inventories in the Macaronesian islands," in Terrestrial Arthropods of Macaronesia - Biodiversity, Ecology and Evolution, eds A. R. M. Serrano, P. A. V. Borges, M. Boieiro, and P. Oromí (Lisboa: Sociedade Portuguesa de Entomologia), 33-47.

López-Darias, M., and Nogales, M. (2016). Raptors as legitimate secondary dispersers of weed seeds. IBIS 158, 428-432. doi: 10.1111/ibi.12360

Loureiro, A., de Almeida, N. F., Carretero, M. A., and Paulo, O. S. (2008). Atlas dos Anfíbios e Répteis de Portugal, $1^{\text {a }}$ edição Edn. Lisboa: Instituto da Conservação da Natureza e da Biodiversidade.

Lundgren, E. J., Ramp, D., Rowan, J., Middleton, O., Schowanek, S. D., Sanisidro, O., et al. (2020). Introduced herbivores restore Late Pleistocene ecological functions. Proc. Natl. Acad. Sci. U.S.A. 117, 7871-7878. doi: 10.1073/pnas. 1915769117

MacArthur, R. H., and Wilson, E. O. (1963). An equilibrium theory of insular zoogeography. Evolution 17, 373-387. doi: 10.2307/2407089

MacArthur, R. H., and Wilson, E. O. (1967). The Theory of Island Biogeography. Princeton, NJ: Princeton University Press.

Machado, A., Rodríguez-Expósito, E., López, M., and Hernández, M. (2017). Phylogenetic analysis of the genus Laparocerus, with comments on colonisation and diversification in Macaronesia (Coleoptera, Curculionidae, Entiminae). Zookeys 651, 1-77. doi: 10.3897/zookeys.651.10097

Macías-Hernández, N., Ramos, C., Domènech, M., Febles, S., Santos, I., Arnedo, M. A., et al. (2020). A database of functional traits for spiders from native forest of the Iberian Peninsula and Macaronesia. Biodivers. Data J. 8:e49159. doi: 10.3897/BDJ.8.e49159

Madeira, J., Mata, J., Mourão, C., Brum da Silveira, A., Martins, S., Ramalho, R., et al. (2010). Volcano- stratigraphic and structural evolution of Brava Island (Cape Verde) based on $40 \mathrm{Ar} / 39 \mathrm{Ar}$, U-Th and field constraints. J. Volcanol. Geoth. Res. 196, 219-235. doi: 10.1016/j.jvolgeores.2010.07.010

Madeira, J., Munhá, J., Tassinari, C. C. G., Mata, J., Brum da Silveira, A., and Martins, S. (2005). "K/Ar ages of carbonatites from the Island of Fogo (Cape Verde)," in Proceedings of the XIV semana de Geoquímica/VIII Congresso de Geoquímica dos Países de Língua Portuguesa, Aveiro, 475-478.

Malmqvist, B., Nilsson, N. A., and Báez, M. (1995). Tenerife’s freshwater macroinvertebrates: status and threats (Canary Islands, Spain). Aquat. Conserv. 5, 1-24. doi: 10.1002/aqc.3270050103

Marques, F. O., Hildenbrand, A., Zeyen, H., Cunha, C., and Victória, S. S. (2020). The complex vertical motion of intraplate oceanic islands assessed in Santiago Island, Cape Verde. Geochem. Geophy. Geosyst. 21:e2019GC008754. doi: 10. 1029/2019GC008754

Martín, J. L. (2009). Are the IUCN standard home-range thresholds for species a good indicator to prioritize conservation urgency in small islands? A case study in the Canary Islands (Spain). J. Nat. Conserv. 17, 87-98. doi: 10.1016/j.jnc.2008. 10.001

Martins, G. M., Arenas, F., Neto, A. I., and Jenkins, S. R. (2012). Effects of fishing and regional species pool on the functional diversity of fish communities. PLoS One 7:e44297. doi: 10.1371/journal.pone.0044297

Martins, G. M., Jenkins, S. R., Hawkins, S. J., Neto, A. I., and Thompson, R. C. (2008). Exploitation of rocky intertidal grazers: population status and potential impacts on community structure and functioning. Aquat. Biol. 3, 1-10. doi: $10.3354 / \mathrm{ab} 00072$

Martins, G. M., Neto, A. I., and Cacabelos, E. (2016). Ecology of a key ecosystem engineer on hard coastal infrastructure and natural rocky shores. Mar. Environ. Res. 113, 88-94. doi: 10.1016/j.marenvres.2015.11.013 
Martins, G. M., Thompson, R. C., Neto, A. I., Hawkins, S. J., and Jenkins, S. R. (2010). Exploitation of intertidal grazers as a driver of community divergence. J. Appl. Ecol. 47, 1282-1289. doi: 10.1111/j.1365-2664.2010.01876.x

Meco, J., Gillou, H., Carracedo, J. C., Lomoschitz, A., Ramos, A. J. G., and Rodríguez-Yánez, J. J. (2002). The maximum warmings of the Pleistocene world climate recorded in the Canary Islands. Palaeogeogr. Palaeoclimatol. Palaeoecol. 185, 197-210. doi: 10.1016/S0031-0182(02)00300-0

Miralles, A., Vasconcelos, R., Perera, A., Harris, D. J., and Carranza, S. (2011). An integrative taxonomic revision of the Cape Verdean skinks (Squamata, Scincidae). Zool. Scr. 40, 16-44. doi: 10.1111/j.1463-6409.2010.00453.x

Moore, N. W. (1975). The diurnal flight of the Azorean bat (Nyctalus azoreum) and the avifauna of the Azores. J. Zool. 177, 483-486. doi: 10.1111/j.1469-7998.1975. tb02248.x

Moro, L., Martín, J. L., Garrido, M. J., and Izquierdo, I. (2003). Lista de Especies Marinas de Canarias (Algas, Hongos, Plantas y Animales) 2003. Las Palmas: Consejería de Política Territorial y Medio Ambiente del Gobierno de Canarias.

Mort, M. E., Soltis, D. E., Soltis, P. S., Francisco-Ortega, J., and Santos-Guerra, A. (2002). Phylogenetics and evolution of the Macaronesian clade of Crassulaceae inferred from nuclear and chloroplast sequence data. Syst. Bot. 27, 281-288. doi: 10.1043/0363-6445-27.2.271

Mort, M. E., Soltis, D. E., Soltis, P. S., Francisco-Ortega, J., and Santos-Guerra, A. (2001). Phylogenetic relationships and evolution of Crassulaceae inferred from matK sequence data. Am. J. Bot. 88, 76-91. doi: 10.2307/2657129

Nattier, R., Pellens, R., Robillard, T., Jourdan, H., Legendre, F., Caesar, M., et al. (2017). Updating the phylogenetic dating of New Caledonian biodiversity with a meta-analysis of the available evidence. Sci. Rep. 7:3705. doi: 10.1038/s41598017-02964-x

Navarro, P. G., Ramírez, R., Tuya, F., Fernandez-Gil, C., Sánchez-Jeréz, P., and Haroun, R. J. (2005). Hierarchical analysis of spatial distribution patterns of patellid limpets in the Canary Islands. J. Moll. Stud. 71, 67-73. doi: 10.1093/ mollus/eyio09

Neto, A. I. A., Moreu, I., Alquicira, E. F. R., León-Cisneros, K., Cacabelos, E., Botelho, A. Z., et al. (2021a). Marine algal flora of São Miguel Island, Azores. Biodivers. Data J. 9:e64969. doi: 10.3897/BDJ.9.e64969

Neto, A. I. A., Parente, M. I., Cacabelos, E., Costa, A. C., Botelho, A. Z., Ballesteros, E., et al. (2021c). Marine algal flora of Santa Maria Island, Azores. Biodivers. Data J. 9:e61909. doi: 10.3897/BDJ.9.e61909

Neto, A. I. A., Parente, M. I., Tittley, I., Fletcher, R. L., Farnham, W., Costa, A. C., et al. (2021b). Marine algal flora of Flores and Corvo Islands, Azores. Biodivers. Data J. 9, e60929. doi: 10.3897/BDJ.9.e60929

Neto, C., Costa, J. C., Figueiredo, A., Capelo, J., Gomes, I., Vitória, S., et al. (2020). The role of climate and topography in shaping the diversity of plant communities in Cabo Verde Islands. Diversity 12:80. doi: 10.3390/d120 20080

Nogales, M., Heleno, R., Rumeu, B., González-Castro, A., Traveset, A., Vargas, P., et al. (2016). Seed-dispersal networks on the Canaries and the Galápagos: interaction modules as biogeographical entities. Glob. Ecol. Biogeogr. 25, $912-$ 922. doi: 10.1111/geb.12315

Nogales, M., Heleno, R., Traveset, A., and Vargas, P. (2012). Evidence for overlooked mechanisms of long-distance seed dispersal to and between oceanic islands. New Phytol. 194, 313-317. doi: 10.1111/j.1469-8137.2011.04051.x

Nogales, M., Medina, F. M., Quilis, V., and González-Rodríguez, M. (2001). Ecological and biogeographical implications of Yellow-Legged gull Larus cachinnans Pallas as seed dispersers of Rubia fruticosa Ait. Rubiaceae in the Canary Islands. J. Biogeogr. 28, 1137-1145. doi: 10.1046/j.1365-2699.2001. 00622.x

Nogué, S., de Nascimento, L., Fernández-Palacios, J. M., Whittaker, R. J., and Willis, K. J. (2013). The ancient forests of La Gomera, Canary Islands, and their sensitivity to environmental change. J. Ecol. 101, 368-377. doi: 10.1111/13652745.12051

Nogué, S., de Nascimento, L., Froyd, C. A., Wilmshurst, J. M., de Boer, E. J., Coffey, E. D., et al. (2017). Island biodiversity conservation needs palaeoecology. Nat. Ecol. Evol. 1:0181. doi: 10.1038/s41559-017-0181

Nogué, S., Santos, A. M., Birks, H. J. B., Björck, S., Castilla-Beltrán, A., Connor, S., et al. (2021). The human dimension of biodiversity changes on islands. Science 372, 488-491. doi: 10.1126/science.abd6706

Norder, S. J., De Lima, R. F., De Nascimento, L., Lim, J. Y., FernandezPalacios, J. M., Romeiras, M. M., et al. (2020). Global change in microcosms: environmental and societal predictors of land cover change on the Atlantic Ocean Islands. Anthropocene 30:10042. doi: 10.1016/j.ancene.2020.100242

Olesen, J. M., and Valido, A. (2003). Lizards as pollinators and seed dispersers: an island phenomenon. Trends Ecol. Evol. 18, 177-181. doi: 10.1016/S01695347(03)00004- 1

Olivera, P., Menezes, D., Trout, R., Buckle, A., Geraldes, P., and Jesus, J. (2010). Successful eradication of the European rabbit (Oryctolagus cuniculus) and house mouse (Mus musculus) from the island of Selvagen Grande (Macaronesian archipelago), in the Eastern Atlantic. Integr. Zool. 5, 70-83. doi: 10.1111/j.17494877.2010.00186.x

Padilla, D. P., González-Castro, A., and Nogales, M. (2012). Significance and extent of secondary seed dispersal by predatory birds on oceanic islands: the case of the Canary archipelago. J. Ecol. 100, 416-427. doi: 10.1111/j.1365-2745.2011.01 924.x

Padrón, B., Traveset, A., Biedenweg, T., Díaz, D., Nogales, M., and Olesen, J. M. (2009). Impact of alien plant invaders on pollination networks in two archipelagos. PLoS One 4:e6275. doi: 10.1371/journal.pone.0006275

Paris, R., Ramalho, R. S., Madeira, J., Ávila, S. P., May, S. M., Rixhon, G., et al. (2018). Megatsunami conglomerates on the flanks of oceanic shield volcanoes. Mar. Geol. 395, 168-187. doi: 10.1016/j.margeo.2017.10.004

Patiño, J., and Vanderpoorten, A. (2015). Macaronesia is a departure gate of anagenetic speciation in the moss genus Rhynchostegiella. J. Biogeogr. 42, 2122-2130. doi: 10.1111/jbi.12583

Patiño, J., Carine, M. A., Mardulyn, P., Devos, N., Mateo, R. G., GonzálezMancebo, J. M., et al. (2015). Approximate Bayesian computation reveals the crucial role of oceanic islands for the assembly of continental biodiversity. Syst. Biol. 64, 579-589. doi: 10.1093/sysbio/syv013

Patiño, J., Guilhaumon, F., Whittaker, R. J., Triantis, K. A., Gradstein, S. R., Hedenäs, L., et al. (2013). Accounting for data heterogeneity in patterns of biodiversity: an application of linear mixed effect models to the oceanic island biogeography of spore-producing plants. Ecography 36, 904-913. doi: 10.1111/ j.1600-0587.2012.00020.x

Patiño, J., Mateo, R. G., Zanatta, F., Marquet, A., Aranda, S. C., Borges, P. A. V., et al. (2016). Climate threat on the Macaronesian endemic bryophyte flora. Sci. Rep. 6:29156. doi: 10.1038/srep29156

Patiño, J., Whittaker, R. J., Borges, P. A. V., Fernández-Palacios, J. M., Ah-Peng, C., Araujo, M. B., et al. (2017). A roadmap for island biology: 50 fundamental questions after 50 years of The Theory of Island Biogeography. J. Biogeogr. 44, 963-983. doi: 10.1111/jbi.12986

Pérez-Méndez, N., Jordano, P., and Valido, A. (2018). Persisting in defaunated landscapes: reduced plant population connectivity after seed dispersal collapse. J. Ecol. 106, 936-947. doi: 10.1111/1365-2745.12848

Pérez-Méndez, N., Jordano, P., García, C., and Valido, A. (2016). The signatures of Anthropocene defaunation: cascading effects of the seed dispersal collapse. Sci. Rep. 6:24820. doi: 10.1038/srep24820

Picanço, A., Rigal, F., Matthews, T. J., Cardoso, P., and Borges, P. A. V. (2017). Impact of land-use change on flower-visiting insect communities on an oceanic island. Insect Conserv. Diver. 10, 211-223. doi: 10.1111/icad.12216

Pinho, C. J., Santos, B., Mata, V. A., Seguro, M., Romeiras, M. M., Lopes, R. J., et al. (2018). What is the giant wall gecko having for dinner? Conservation genetics for guiding reserve management in Cabo Verde. Genes 9:599. doi: 10.3390/genes9120599

Pipan, T., López, H., Oromí, P., Polack, S., and Culver, D. C. (2010). Temperature variation and the presence of troglobionts in terrestrial shallow subterranean habitats. J. Nat. Hist. 45, 253-273. doi: 10.1080/00222933.2010. 523797

Planas, E., and Ribera, C. (2014). Uncovering overlooked island diversity: colonization and diversification of the medically important spider genus Loxosceles (Arachnida: Sicariidae) on the Canary Islands. J. Biogeogr. 41, 12551266. doi: 10.1111/jbi.12321

Ramalho, R. S. (2011). Building the Cape Verde Islands, 1st Edn. Berlin: Springer Science \& Business Media.

Ramalho, R. S., Brum Da Silveira, A., Fonseca, P. E., Madeira, J., Cosca, M., Cachão, M., et al. (2015). The emergence of volcanic oceanic islands on a slow-moving plate: the example of Madeira Island, NE Atlantic. Geochem. Geophy. Geosyst. 16, 522-537. doi: 10.1002/2014GC005657

Ramalho, R. S., Helffrich, G., Madeira, J., Cosca, M., Thomas, C., Quartau, R., et al. (2017). The emergence and evolution of Santa Maria Island (Azores) - 
the conundrum of uplifted islands revisited. Bull. Geol. Soc. Am. 129, 372-390. doi: $10.1130 / \mathrm{B} 31538.1$

Rando, J. C., Alcover, J. A., and Illera, J. C. (2010). Disentangling ancient interactions: a new extinct passerine provides insights on character displacement among extinct and extant island finches. PLoS One 5:e12956. doi: 10.1371/journal.pone.0012956

Rando, J. C., Alcover, J. A., Pieper, H., Olson, S. L., Hernández, C. N., and LópezJurado, L. F. (2020). Unforeseen diversity of quails (Galliformes: Phasianidae: Coturnix) in oceanic islands provided by the fossil record of Macaronesia. Zool. J. Linn. Soc. Lond. 188, 1296-1317. doi: 10.1093/zoolinnean/zlz107

Rando, J. C., Pieper, H., and Alcover, J. A. (2014). Radiocarbon evidence for house mouse presence on Madeira Island (North Atlantic) one millennium ago. Proc. R. Soc. B 281, 2023-2029. doi: 10.1098/rspb.2013.3126

Raposeiro, P. M., Hughes, S. J., Costa, A. C., and Cruz, A. M. (2012). Azorean freshwater invertebrates: status, threats and biogeographic notes. Limnetica 31, 13-22.

Raposeiro, P. M., Rubio, M. J., González, A., Hernández, A., Sánchez-López, G., Vázquez-Loureiro, D., et al. (2017). Impact of the historical introduction of exotic fishes on the chironomid community of Lake Azul (Azores Islands). Palaeogeogr. Palaeoclimatol. Palaeoecol. 466, 77-88. doi: 10.1016/j.palaeo.2016. 11.015

Reyes-Betancort, J. A., Santos Guerra, A., Guma, I. R., Humphries, C. J., and Carine, M. A. (2008). Diversity, rarity and the evolution and conservation of the Canary Islands endemic flora. An. Jardin Bot. Madr. 65, 25-45. doi: 10.3989/ajbm.2008.v65.i1.244

Ribeiro, F., Collares-Pereira, M. J., and Moyle, P. B. (2009). Non-native fish in the fresh waters of Portugal, Azores and Madeira Islands: a growing threat to aquatic biodiversity. Fisheries Manag. Ecol. 16, 255-264. doi: 10.1111/j.13652400.2009.00659.x

Ribeiro, S. P., Borges, P. A. V., Gaspar, C., Melo, C., Serrano, A. R. M., Amaral, J., et al. (2005). Canopy insect herbivore diversity and distribution in the native forests of the Azores: key host plant species in a highly generalist insect community. Ecography 28, 315-330. doi: 10.1111/j.0906-7590.2005.04104.x

Rigal, F., Cardoso, P., Lobo, J. M., Triantis, K. A., Whittaker, R. J., Amorim, I. R., et al. (2018). Functional traits of indigenous and exotic ground-dwelling arthropods show contrasting responses to land-use change in an oceanic island, Terceira, Azores. Divers. Distrib. 24, 36-47. doi: 10.1111/ddi.12655

Rijsdijk, K. F., Hengl, T., Norder, S. J., Otto, R., Emerson, B. C., Ávila, S. P., et al. (2014). Quantifying surface-area changes of volcanic islands driven by Pleistocene sea-level cycles: biogeographical implications for the Macaronesian archipelagos. J. Biogeogr. 41, 1242-1254. doi: 10.1111/jbi.12336

Ritter, C., Raposeiro, P. M., and Gonçalves, V. (2020). Diatom diversity and distribution in Madeira Island streams (Portugal). Biodivers. Data J. 8:e59813. doi: 10.3897/BDJ.8.e59813

Romeiras, M. M., Carine, M., Duarte, M. C., Catarino, S., Dias, F. S., and Borda-deÁgua, L. (2020). Bayesian methods to analyze historical collections in time and space: a case study using Cabo Verde endemic flora. Front. Plant Sci. 11:278. doi: $10.3389 /$ fpls.2020.00278

Romeiras, M. M., Catarino, S., Filipe, A. F., Magalhães, M. F., Duarte, M. C., and Beja, P. (2016b). Species conservation assessments in oceanic islands: the consequences of precautionary versus evidentiary attitudes. Conserv. Lett. 9, 275-280. doi: 10.1111/conl.12212

Romeiras, M. M., Catarino, S., Gomes, I., Fernandes, C., Costa, J. C., CaujapéCastells, J., et al. (2016a). IUCN Red List assessment of the Cape Verde endemic flora: towards a Global Strategy for Plant Conservation in Macaronesia. Bot. J. Linn. Soc. 180, 413-425. doi: 10.1111/boj.12370

Romeiras, M. M., Pena, A. R., Menezes, T., Vasconcelos, R., Monteiro, F., Paulo, O. S., et al. (2019). Shortcomings of phylogenetic studies on recent radiated insular groups: a meta-analysis using Cabo Verde biodiversity. Int. J. Mol. Sci. 20:2782. doi: 10.3390/ijms20112782

Rull, V., Lara, A., Rubio-Ingles, M. J., Giralt, S., Gonçalves, V., Raposeiro, P., et al. (2017). Vegetation and landscape dynamics under natural and anthropogenic forcing on the Azores Islands: a 700-year pollen record from the São Miguel Island. Quat. Sci. Rev. 159, 155-168. doi: 10.1016/j.quascirev.2017.01.021

Russell, J. C., and Kueffer, K. (2019). Island Biodiversity in the Anthropocene. Annu. Rev. Env. Resour. 44, 31-60. doi: 10.1146/annurev-environ-101718033245
Sadek, R. A. (1981). The diet of the Madeiran lizard Lacerta dugesii. Zool. J. Linn. Soc. 73, 313-341. doi: 10.1111/j.1096-3642.1981.tb01599.x

Salces-Castellano, A., Patiño, J., Alvarez, N., Andújar, C., Arribas, P., Braojos-Ruiz, J. J., et al. (2020). Climate drives community-wide divergence within species over a limited spatial scale: evidence from an oceanic island. Ecol. Lett. 23, 305-315. doi: 10.1111/ele.13433

Salvador, A. (2015). "Lagarto gigante de El Hierro - Gallotia simonyi (Steindachner, 1889)," in Enciclopedia Virtual de los Vertebrados Españoles, eds A. Salvador and A. Marco (Madrid: Museo Nacional de Ciencias Naturales).

Samrock, L. K., Wartho, J. A., Hansteen, T. H., and Dullo, C. (2018). "Crumbling Away: $40 \mathrm{Ar}-39 \mathrm{Ar}$ dating of a large miocene mass wasting period on Maio Island (Cape Verde)," in Proceedings of the American Geophysical Union, Fall Meeting Abstracts 2018,V23L-0205, Washington, DC.

Santos, A. M. C., Field, R., and Ricklefs, R. E. (2016). New directions in island biogeography. Glob. Ecol. Biogeogr. 25, 751-768. doi: 10.1111/geb.1 2477

Santos, A. M. C., Fontaine, C., Quicke, D. L. J., Borges, P. A. V., and Hortal, J. (2011). Are island and mainland biotas different? Richness and level of generalism in parasitoids of a microlepidopteran in Macaronesia. Oikos 120, 1256-1262. doi: 10.1111/j.1600-0706.2010.19404.x

Santos, A. M. C., Whittaker, R. J., Triantis, K. A., Borges, P. A. V., Jones, O. R., Quicke, D. L. J., et al. (2010). Are species-area relationships from entire archipelagos congruent with those of their constituent islands? Glob. Ecol. Biogeogr. 19, 527-540. doi: 10.1111/j.1466-8238.2010.00536.x

Santos, A., Mayoral, E., Dumont, C. P., da Silva, C. M., Ávila, S. P., Baarli, B. G., et al. (2015). Role of environmental change in rock-boring echinoid trace fossils. Palaeogeogr. Palaeoclimatol. Palaeoecol. 432, 1-14. doi: 10.1016/j.palaeo.2015. 04.029

Schaefer, H., Hardy, O. J., Silva, L., Barraclough, T. G., and Savolainen, V. (2011). Testing Darwin's naturalization hypothesis in the Azores. Ecol. Lett. 14, 389396. doi: 10.1111/j.1461-0248.2011.01600.x

Sérusiaux, E., Villarreal, A. J. C., Wheeler, T., and Goffinet, B. (2011). Recent origin, active speciation and dispersal for the lichen genus Nephroma (Peltigerales) in Macaronesia. J. Biogeogr. 38, 1138-1151. doi: 10.1111/j.1365-2699.2010.02 469. $\mathrm{x}$

Silva, L., Ojeda Land, E., and Rodríguez Luengo, J. L. (2008). Invasive Terrestrial Flora and Fauna of Macaronesia. Top 100 in Azores, Madeira and Canaries. Ponta Delgada: ARENA.

Skov, T., Buchaca, T., Amsinck, S. L., Landkildehus, F., Odgaard, B. V., Azevedo, J., et al. (2010). Using invertebrate remains and pigments in the sediment to infer changes in trophic structure after fish introduction in Lake Fogo: a crater lake in the Azores. Hydrobiologia 654, 13-25. doi: 10.1007/s10750-010-0325-5

Sobral, F. L., Lees, A. C., and Cianciaruso, M. V. (2016). Introductions do not compensate for functional and phylogenetic losses following extinctions in insular bird assemblages. Ecol. Lett. 19, 1091-1100. doi: 10.1111/ele.12646

Sousa, R., Vasconcelo, J., Vera-Escalona, I., Rita, A., Hawkins, S., Freitas, M., et al. (2021). Pleistocene expansion, anthropogenic pressure and ocean currents: disentangling the past and ongoing evolutionary history of Patella aspera Röding, 1798 in the archipelago of Madeira. Mar. Environ. Res. 105485. doi: $10.22541 / \mathrm{au} .162607542 .26351545 / \mathrm{v} 1$

SPEA (2006). Recuperação do habitat do Azores Bullfinch na ZPE Pico da Vara/Ribeirado Guilherme LIFE 03NAT/P/000013 - $2^{\circ}$ Relatório de Progresso. Lisboa: Sociedade Portuguesa para o Estudo das Aves.

Spurgin, L. G., Illera, J. C., Jorgensen, T. H., Dawson, D. A., and Richardson, D. S. (2014). Genetic and phenotypic divergence in an island bird: isolation by distance, by colonization or by adaptation? Mol. Ecol. 23, 1028-1039. doi: $10.1111 /$ mec. 12672

Steinbauer, M. J., Field, R., Fernández-Palacios, J. M., Irl, S. D., Otto, R., Schaefer, H., et al. (2016). Biogeographic ranges do not support niche theory in radiating Canary Island plant clades. Glob. Ecol. Biogeogr. 25, 792-804. doi: 10.1111/geb. 12425

Stüben, P. E., Behne, L., Floren, A., Günthe, H., Klopfstein, S., López, H., et al. (2010). Canopy fogging in the Canarian laurel forest of Tenerife and La Gomera. Weevil News 51, 1-21.

Stuessy, T. F., Takayama, K., and Sepúlveda, P. L. (2012). Founder effects are invisible in endemic species of oceanic Islands. J. Biogeogr. 39, 1565-1566. doi: $10.1111 / j .1365-2699.2012 .02768 . x$ 
Torres, P. C., Silva, L. C., Serralheiro, A., Tassinari, C., and Munhá, J. (2002). Enquadramento geocronológico pelo método K/Ar das principais sequências vulcano-estratigráficas da Ilha do Sal-Cabo Verde. Garcia Orta Sér. Geol. 18, 9-13.

Traveset, A., Heleno, R., Chamorro, S., Vargas, P., McMullen, C. K., Castro-Urgal, R., et al. (2013). Invaders of pollination networks in the Galápagos Islands: emergence of novel communities. Proc. R. Soc. B 280:20123040. doi: 10.1098/ rspb. 2012.3040

Traveset, A., Olesen, J. M., Nogales, M., Vargas, P., Jaramillo, P., Antolín, E., et al. (2015). Bird-flower visitation networks in the Galápagos unveil a widespread interaction release. Nat. Commun. 6:6376. doi: 10.1038/ncomms7376

Triantis, K. A., Borges, P. A. V., Ladle, R. J., Hortal, J., Cardoso, P., Gaspar, C., et al. (2010). Extinction debt on oceanic islands. Ecography 33, 285-294. doi: 10.1111/j.1600-0587.2010.06203.x

Triantis, K., Hortal, J., Amorim, I., Cardoso, P., Santos, A. M. C., Gabriel, R., et al. (2012). Resolving the Azorean knot: a response to Carine \& Schaefer (2010). J. Biogeogr. 39, 1179-1184. doi: 10.1111/j.1365-2699.2011.02623.x

Trøjelsgaard, K., Báez, M., Espadaler, X., Nogales, M., Oromí, P., Roche, L. F., et al. (2013). Island biogeography of mutualistic interaction networks. J. Biogeogr. 40, 2020-2031. doi: 10.1111/jbi.12165

Tuya, F., and Haroun, R. (2009). Phytogeography of Lusitanian Macaronesia: biogeographic affinities in species richness and assemblage composition. Eur. J. Phycol. 44, 405-413. doi: 10.1080/09670260902836246

Ulrich, W., and Zalewski, M. (2006). Abundance and co-occurrence patterns of core and satellite species of ground beetles on small lake islands. Oikos 114, 338-348. doi: 10.1111/j.2006.0030-1299.14773.x

Valente, L., Illera, J. C., Havenstein, K., Pallien, T., Etienne, R. S., and Tiedemann, R. (2017). Equilibrium bird species diversity in Atlantic Islands. Curr. Biol. 27, 1660-1666. doi: 10.1016/j.cub.2017.04.053

Valente, L., Phillimore, A. B., Melo, M., Warren, B. H., Clegg, S. M., Havenstein, K., et al. (2020). A simple dynamic model explains island bird diversity worldwide. Nature 579, 92-96. doi: 10.1038/s41586-020-2022-5

Valido, A., and Nogales, M. (1994). Frugivory and seed dispersal by the lizard Gallotia galloti (Lacertidae) in a xeric habitat of the Canary Islands. Oikos 70, 403-411. doi: 10.2307/3545778

Valido, A., and Olesen, J. M. (2010). "Pollination on islands: examples from the Macaronesian archipelagos," in Terrestrial Arthropods of Macaronesia. Biodiversity, Ecology and Evolution, eds A. R. M. Serrano, P. A. V. Borges, M. Boieiro, and P. Oromí (Lisboa: Sociedade Portuguesa de Entomologia), 249-283.

Valido, A., and Olesen, J. M. (2019). Frugivory and seed dispersal by lizards: a global review. Front. Ecol. Evol. 7:49. doi: 10.3389/fevo.2019.00049

Valido, A., Dupont, Y. L., and Hansen, D. M. (2002). Native birds and insects, and introduced honey bees visiting Echium wildpretii (Boraginaceae) in the Canary Islands. Acta Oecol. 23, 413-419. doi: 10.1016/S1146-609X(02)01167-0

Valido, A., Dupont, Y. L., and Olesen, J. M. (2004). Bird-flower interactions in the Macaronesian islands. J. Biogeogr. 31, 1945-1953. doi: 10.1111/j.1365-2699. 2004.01116.x

Valido, A., Rodrí́guez-Rodriíguez, M. C., and Jordano, P. (2019). Honeybees disrupt the structure and functionality of plant-pollinator networks. Sci. Rep. 9:4711. doi: 10.1038/s41598-019-41271-5

van den Bogaard, P. (2013). The origin of the Canary Island Seamount Province-New ages of old seamounts. Sci. Rep. 3:2107. doi: 10.1038/srep0 2107

Van Leeuwen, J. F. N., Schäfer, H., van der Knaap, W. O., Rittenour, T., Björck, S., and Ammann, B. (2005). Native or introduced? Fossil pollen and spores may say. An example from the Azores Islands. Neobiota 6, 27-34.

Vargas, P. (2007). "Are Macaronesian islands refugia of relict plant lineages? A molecular survey," in Phylogeography of Southern European Refugia, eds S. Weiss and N. Ferrand (Dordrecht: Springer), 297-314.

Vasconcelos, R., Brito, J. C., Carranza, S., and Harris, D. J. (2013). Review of the distribution and conservation status of the terrestrial reptiles of the Cape Verde Islands. Oryx 47, 77-87. doi: 10.1017/S0030605311001438

Vasconcelos, R., Brito, J. C., Carvalho, S., Carranza, S., and Harris, D. J. (2012a). Identifying priority areas for island endemics using genetic versus specific diversity - the case of the terrestrial reptiles of the Cape Verde Islands. Biol. Conserv. 153, 276-286. doi: 10.1016/j.biocon.2012.04.020

Vasconcelos, R., Carranza, S., and Harris, D. J. (2010). Insight into an island radiation: the Tarentola geckos of the Cape Verde archipelago. J. Biogeogr. 37, 1047-1060. doi: 10.1111/j.1365-2699.2009.02254.x

Vasconcelos, R., Köhler, G., Geniez, P., and Crochet, P. A. (2020). A new endemic species of Hemidactylus (Squamata: Gekkonidae) from São Nicolau Island, Cabo Verde. Zootaxa 4878, 501-522. doi: 10.11646/zootaxa.4878.3.4

Vasconcelos, R., Perera, A. N. A., Geniez, P., Harris, D. J., and Carranza, S. (2012b). An integrative taxonomic revision of the Tarentola geckos (Squamata, Phyllodactylidae) of the Cape Verde Islands. Zoo. J. Linn. Soc. Lond. 164, 328-360. doi: 10.1111/j.1096-3642.2011.00768.x

Vergílio, M., Fonseca, C., Calado, H., Borges, P. A. V., Elias, R. B., Gabriel, R., et al. (2016). Assessing the efficiency of protected areas to represent biodiversity: a small island case study. Environ. Conserv. 43, 337-349. doi: 10.1017/S0376892916000230

Viana, D. S., Gangoso, L., Bouten, W., and Figuerola, J. (2016). Overseas seed dispersal by migratory birds. Proc. R. Soc. B 283:20152406. doi: 10.1098/rspb. 2015.2406

Villacorta, C., Jaume, D., Oromí, P., and Juan, C. (2008). Under the volcano: phylogeography and evolution of the cave-dwelling Palmorchestia hypogaea (Amphipoda, Crustacea) at La Palma (Canary Islands). BMC Evol. Biol. 6:7. doi: 10.1186/1741-7007-6-7

Weigelt, P., Steinbauer, M. J., Cabral, J. S., and Kreft, H. (2016). Late Quaternary climate change shapes island biodiversity. Nature 532, 99-102. doi: 10.1038/ nature 17443

Weissmann, J. A., Picanço, A., Borges, P. A. V., and Schaefer, H. (2017). Bees of the Azores: an annotated checklist (Apidae, Hymenoptera). ZooKeys 642, 63-95. doi: $10.3897 /$ zookeys.642.10773

Whittaker, R. J., Fernández-Palacios, J. M., Matthews, T. A., Borregaard, M. K., and Triantis, K. A. (2017). Island biogeography: taking the long view of nature's laboratories. Science 357:eaam8326. doi: 10.1126/science.aam8326

Whittaker, R. J., Rigal, F., Borges, P. A. V., Cardoso, P., Terzopoulou, S., Casanoves, F., et al. (2014). Functional biogeography of oceanic islands and the scaling of functional diversity in the Azores. Proc. Natl. Acad. Sci. U.S.A. 111, 1370913714. doi: 10.1073/pnas.1218036111

Whittaker, R. J., Triantis, K. A., and Ladle, R. J. (2008). A general dynamic theory of oceanic island biogeography. J. Biogeogr. 35, 977-994. doi: 10.1111/j.13652699.2008.01892.x

Wiens, J. J., and Graham, C. H. (2005). Niche conservatism: integrating evolution, ecology, and conservation biology. Annu. Rev. Ecol. Evol. Syst. 36, 519-539. doi: 10.1146/annurev.ecolsys.36.102803.095431

Wilson, E. O. (1961). The nature of the taxon cycle in the Melanesian ant fauna. Am. Nat. 95, 169-193. doi: 10.1086/282174

Conflict of Interest: The authors declare that the research was conducted in the absence of any commercial or financial relationships that could be construed as a potential conflict of interest.

Publisher's Note: All claims expressed in this article are solely those of the authors and do not necessarily represent those of their affiliated organizations, or those of the publisher, the editors and the reviewers. Any product that may be evaluated in this article, or claim that may be made by its manufacturer, is not guaranteed or endorsed by the publisher.

Copyright (C) 2021 Florencio, Patiño, Nogué, Traveset, Borges, Schaefer, Amorim, Arnedo, Ávila, Cardoso, de Nascimento, Fernández-Palacios, Gabriel, Gil, Gonçalves, Haroun, Illera, López-Darias, Martínez, Martins, Neto, Nogales, Oromí, Rando, Raposeiro, Rigal, Romeiras, Silva, Valido, Vanderpoorten, Vasconcelos and Santos. This is an open-access article distributed under the terms of the Creative Commons Attribution License (CC BY). The use, distribution or reproduction in other forums is permitted, provided the original author(s) and the copyright owner(s) are credited and that the original publication in this journal is cited, in accordance with accepted academic practice. No use, distribution or reproduction is permitted which does not comply with these terms. 